\title{
Mexican Demand for U.S. Natural Gas
}

D.m

by M.A. Kanter and P.H. Kier

Environmental Assessment and Information Sciences Division,

Argonne National Laboratory, 9700 South Cass Avenue, Argonne, Illinois 60439

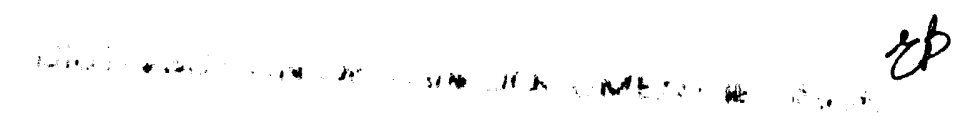




\section{CONTENTS}

ACKNOWLEDGMENTS $\ldots \ldots \ldots \ldots \ldots \ldots \ldots \ldots \ldots \ldots \ldots \ldots \ldots \ldots \ldots$ vi

NOTATION $\ldots \ldots \ldots \ldots \ldots \ldots \ldots \ldots \ldots \ldots \ldots \ldots \ldots \ldots \ldots \ldots \ldots \ldots \ldots$ viii

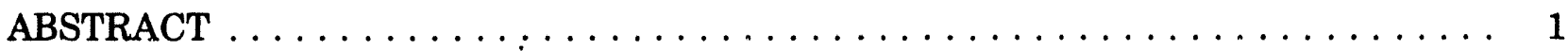

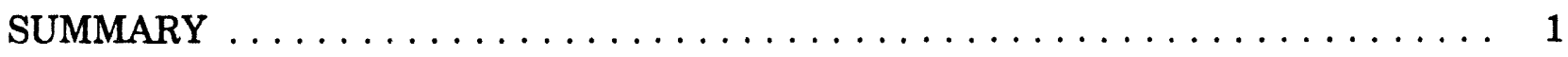

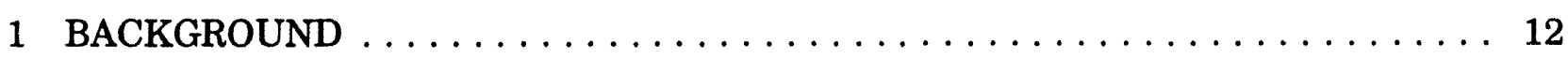

1.1 Objectives and Organization of this Report $\ldots \ldots \ldots \ldots \ldots \ldots \ldots \ldots 12$

1.2 Institutional Framework of Natural Gas Trade with Mexico . . . . . . . 12

1.2.1 History of the Mexican Oil Industry . . . . . . . . . . . . 13

1.2.2 Agencies Whose Policies Impact Natural Gas

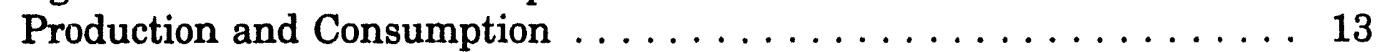

1.2.3 Maquiladora Program $\ldots \ldots \ldots \ldots \ldots \ldots \ldots \ldots \ldots \ldots$

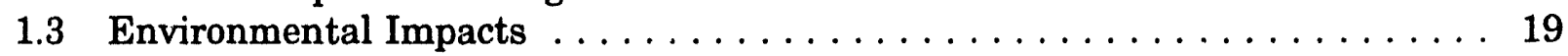

1.4 North American Free Trade Agreement . . . . . . . . . . . . . . 20

2 HISTORICAL PRODUCTION AND CONSUMPTION

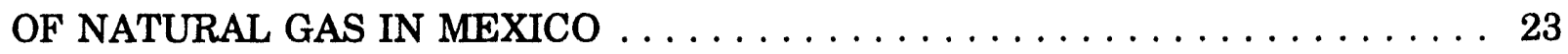

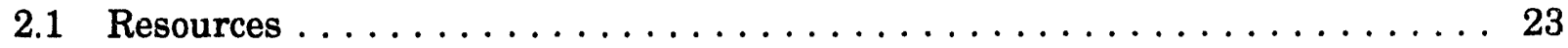

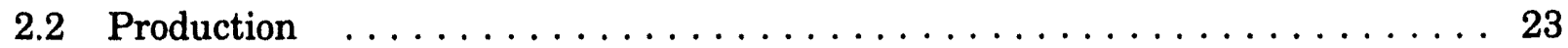

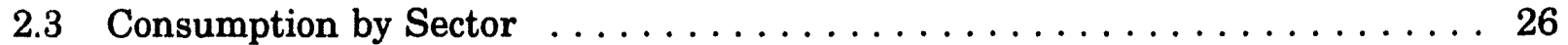

2.3.1 PEMEX Petrochemicals $\ldots \ldots \ldots \ldots \ldots \ldots \ldots \ldots \ldots \ldots 27$

2.3.2 Industrial Sector (Excluding PEMEX) $\ldots \ldots \ldots \ldots \ldots \ldots \ldots 28$

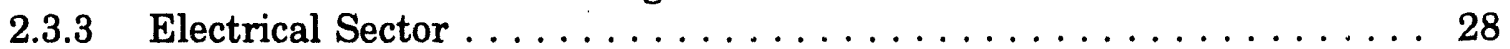

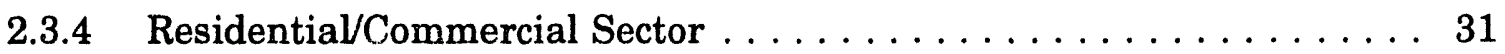

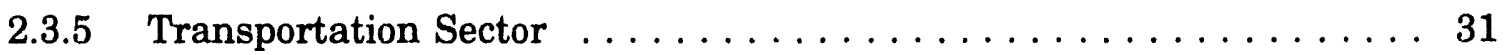

2.4 Mexico's Pipeline Infrastructure $\ldots \ldots \ldots \ldots \ldots \ldots \ldots \ldots \ldots \ldots \ldots \ldots$

2.5 Trade in Natural Gas between the United States and Mexico . . . . . . . . 33

3 FUTURE PRODUCTION AND CONSUMPTION OF NATURAL GAS IN MEXICO $\ldots \ldots \ldots \ldots \ldots \ldots \ldots \ldots \ldots$

3.1 Scenarios for the Mexican Gas Industry $\ldots \ldots \ldots \ldots \ldots \ldots \ldots \ldots$

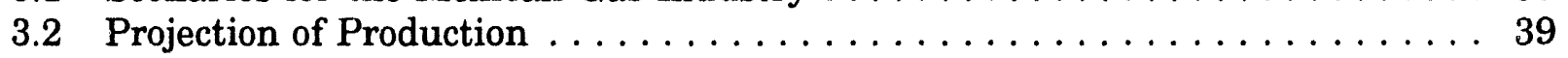

3.3 Projection of Consumption by Sector $\ldots \ldots \ldots \ldots \ldots \ldots \ldots \ldots \ldots \ldots \ldots$

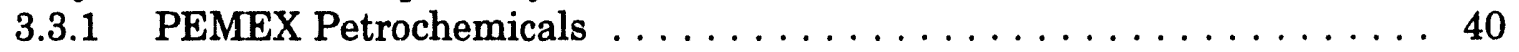

3.3.2 Industrial Sector (Excluding PEMEX) $\ldots \ldots \ldots \ldots \ldots \ldots \ldots \ldots 40$

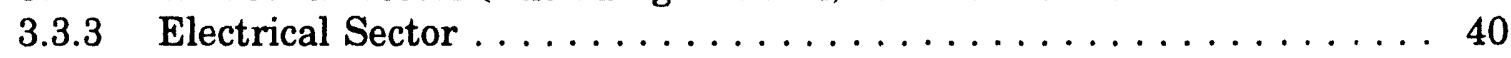

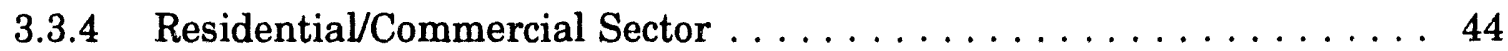

3.3.5 Transportation Sector $\ldots \ldots \ldots \ldots \ldots \ldots \ldots \ldots \ldots \ldots \ldots 4$

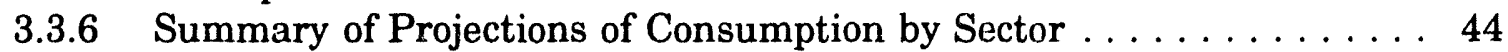

3.4 Additions to the Mexican Pipeline Infrastructure $\ldots \ldots \ldots \ldots \ldots \ldots \ldots$

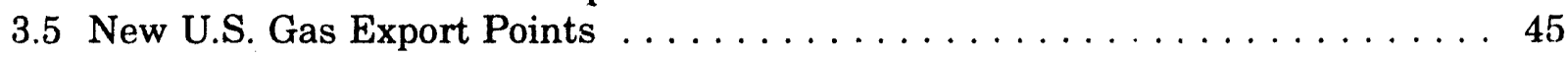




\section{CONTENTS (Cont.)}

4 ESTIMATE OF THE MARKET FOR U.S. EXPORTS $\ldots \ldots \ldots \ldots \ldots \ldots$

4.1 Projection of U.S. Exports of Natural Gas to Mexico . . . . . . . . . . . . 47

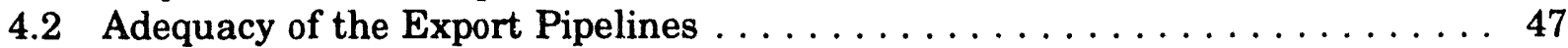

4.3 Balance-of-Payments Considerations . . . . . . . . . . . . . . . 49

4.4 Mexican Political and Economic Considerations . . . . . . . . . . . . 50

4.5 Canada versus the United States as a Supplier of Natural Cas to Mexico . . . . . . . . . . . . . . . . . . . . . . 50

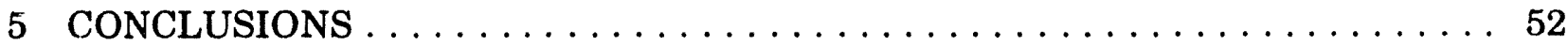

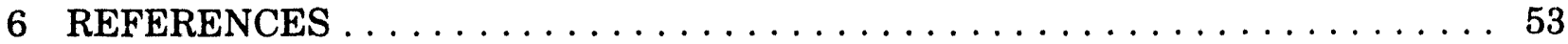

APPENDIX A: Organizational Framework

For Mexican Natural Gas Technology $\ldots \ldots \ldots \ldots 7$

FIGURES

S.1 Map of Mexico Showing Gas Production Regions . . . . . . . . . . . . . . 4

1.1 Map of Mexico $\ldots \ldots \ldots \ldots \ldots \ldots \ldots \ldots \ldots \ldots \ldots \ldots \ldots$

2.1 Natural Gas in Mexico: Production Regions and Pipelines . . . . . . . . . . . . 24

2.2 Production and Consumption of Natural Gas in Mexico, $1992 \ldots \ldots \ldots$

2.3 Natural Gas Used by Mexican Industry Other than PEMEX . . . . . . . . . . 29

2.4 Natural Gas Used in Electrical Generation in Mexico . . . . . . . . . . . 30

2.5 Mexican Gas Industry in 1990: Pipelines and Major

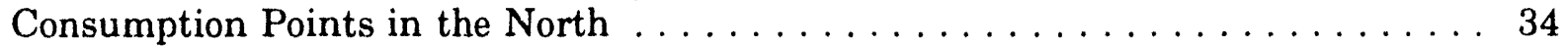

4.1 Use and Projected Use of Natural Gas in Mexico, 1992-2000 . . . . . . . . . . . 49

A.1 Organization of Mexican Federal Government $\ldots \ldots \ldots \ldots \ldots \ldots$

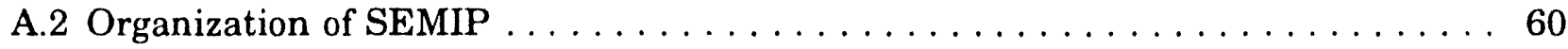

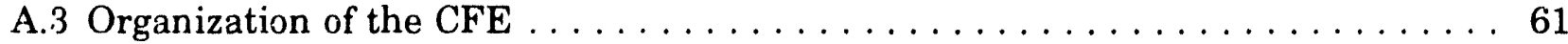




\section{TABLES}

S.1 Projections of U.S. Exports of Natural Gas to Mexico, 1993-2000 _ . . . . . . . 9

1.1 Classification of Petrochemicals $\ldots \ldots \ldots \ldots \ldots \ldots \ldots \ldots \ldots \ldots$

1.2 Operating Subsidiaries of PEMEX $\ldots \ldots \ldots \ldots \ldots \ldots \ldots \ldots \ldots \ldots$

2.1 Mexican Reserves and Production of Natural Gas, 1983-1992 . . . . . . . . . 25

2.2 Production of Natural Gas by Region, $1990-1992 \ldots \ldots \ldots \ldots \ldots \ldots \ldots$

2.3 Gas Consumption by Sector, $1986-1992 \ldots \ldots \ldots \ldots \ldots \ldots \ldots \ldots$

2.4 Local Gas Distribution Companies $\ldots \ldots \ldots \ldots \ldots \ldots \ldots \ldots \ldots \ldots \ldots$

2.5 Size and Use of Major Pipelines in Northern Mexico, $1990 \ldots \ldots \ldots$. . . . . . . . . 35

2.6 Natural Gas Trade between the United States and Mexico, 1977-1992 _ . . . . . 36

2.7 Exports of Natural Gas from the United States to Mexico . . . . . . . . . . 37

3.1 Projection of Consumption of Natural Gas by Sector $\ldots \ldots \ldots \ldots \ldots$. . . .

3.2 Summary of Assumptions for Scenarios A and B . . . . . . . . . . . 42

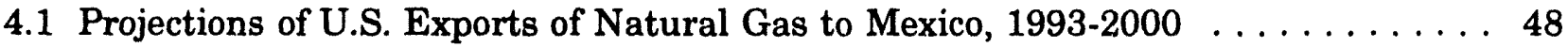

4.2 Value of Petroleum Products Exported from and Imported to Mexico . . . . . . . 50 


\section{ACKNOWLEDGMENTS}

The authors wish to express their appreciation to Luis H. Barojas Weber, Advisor to the Undersecretary for Energy at the Secretariat of Energy, Mines, and Public Industry (SEMIP) for his in-depth introduction to the natural gas industry in Mexico, for hosting Manuel Kanter in November 1992, and for his continuing interest in this study.

The authors also wish to acknowledge Marcela Serrato de Treviño, Washington representative of SEMIP, for her assistance in arranging key appointments for their recent visit to Mexico, in particular for providing timely notice of changes in policy and personnel in the Mexican energy sector and for providing copies of official publications.

Thanks are also due to Juan Eibenschutz, Advisor to the Undersecretary for Energy at SEMIP, who has provided sage advice on the Mexican energy sector to one of the authors for more than 17 years, and to Eduardo Flores, Technical Secretary of the Mexican Petrochemical Commission, for his patience in explaining the vagaries of the Mexican peirochemical industry.

It would not have been possible to prepare this report had the authors not had access to the staff of Mexican Petroleum (PEMEX) Gas and Basic Petrochemicals. The authors thank Delores Nieto Huarte, Senior Advisor to the Director, for providing an overview on PEMEX policy and for arranging meetings with the staff members. Among those who provided valuable insights and information on specific aspects of the study were Augustin Barcenas, Gerardo Bazan, Benjamin Carrion, Horacio Guevara, and Roberto Rodriguez.

The authors would not have been able to understand the role of industry in the demand for exports by the United States without the iñput of Professor Francisco Garcia at the Monterrey Institute of Technology and Higher Education, who provided the outlook on the dynamism of the North of Mexico, and without the statistical information communicated by Gerardo Bazan at PEMEX.

A very important contribution to projecting the timing of increased consumption and the role of privatization in the electrical sector was made by Alberto Blanco and Rafael Cristerna of the Federal Electricity Commission, who provided detailed information on the planning of new gas-fired electrical generating stations.

Luis Vazquez, President of the Mexican Gas Association, provided the outlook of the small but growing private gas industry on the future of gas consumption in the residential/commercial and transportation economic sactors.

The authors also acknowledge the help of Miguel C. de la Peña, Petroleum Attaché at the U.S. Embassy in Mexico, who was always helpful when called upon.

In the United States, Clifford Tomaszewski and John Glynn at the Office of Natural Gas, U.S. Department of Energy, provided the direction that kept the study on track. Richard Foley at the U.S. Federal Energy Regulatory Commission (FERC) was kind enough 
to provide information on the progress of new filings on export pipelines by telephone, which obviated trips to Washington and hours in the FERC document room.

Finally, the authors acknowledge the efforts of Edwin Pentecost, manager of fossil energy projects in the Environmental Assessment and Information Sciences Division, Argonne National Laboratory, who provided guidance on project scope and program objectives. 


\section{NOTATION}

The following is a list of acronyms, initialisms, and abbreviations (including units of measure) that appear in this report.

\section{ACRONYMS, INITIALISMS, AND ABBREVIATIONS*}

BIP Border Industrialization Program

CFE Comision Federal de Electricidad (Federal Electricity Commission)

CNG compressed natural gas

CPM Comisión Petroquimica Mexicana (Mexican Petrochemical Commission)

DDF Departamento del Distrito Federal (Federal District Department)

FERC U.S. Federal Energy Regulatory Commission

IMP Instituto Mexicano para Petroleos (Mexican Petroleum Institute)

INEGI Instituto Nacional de Estadistica, Geografia, y Informatica

(National Institute of Statistics, Geography, and Information)

Ing. Ingeniero (Engineer)

IPP independent power producer(s)

ITESM Instituto Tecnologico y Estudios Superiores de Monterrey (Monterrey Institute of Technology and Higher Education)

Lic. Licenciado (Licenciate: a person with a degree equivalent to Master of Arts)

LPG liquefied petroleum gas

NAFTA North American Free Trade Agreement

PEMEX Petroleos Mexica.1os (Mexican Petroleum)

PMI Petroleos Mexicanos International

* The English names of Mexican governmental organizations given here and used in the text were taken from North American Free Trade Agreement: U.S.-Mexican Trade and Investment Data, GAO/GGD-92-131, U.S. General Accounting Office, September 1992. 


\section{ACRONYMS, INITLALISMS, AND ABBREVIATIONS (Cont.)}

SECOFI Secretaria de Comercio y Fomento Industrial (Secretariat of Trade and Industrial Development)

SEDESOL Secretaria de Desarollo Social (Secretariat of Social Development)

SEDUE Secretaria de Desarollo Urbano y Ecology (Secretariat of Urban Development and Ecology)

SEMIP Secretaria de Energia, Minas, y Industria Paraestatal (Secretariat of Energy, Mines, and Public Industry)

\section{UNITS OF MEASURE}

BCF billion cubic feet

d $\operatorname{day}(\mathrm{s})$

$\mathrm{ft} \quad$ foot (feet)

in. inch(es)

MCF thousand cubic feet

mi mile(s)

MMBtu million British thermal units

MMCF million cubic feet

MW megawatt(s)

MWe megawatts(s) electric

TCF trillion cubic feet

ton $\quad \operatorname{ton}(s)$

TWh terawatt-hour(s)

yr year(s) 


\title{
MEXICAN DEMAND FOR U.S. NATURAL GAS
}

by

\author{
M.A. Kanter and P.H. Kier
}

\begin{abstract}
This study describes the Mexican natural gas industry as it exists today and the factors that have shaped the evolution of the industry in the past or that are expected to influence its progress; it also projects production and use of natural gas and estimates the market for exports of natural gas from the United States to Mexico. The study looks ahead to two periods, a near term (1993-1995) and an intermediate term (1996-2000). The bases for estimates under two scenarios are described. Under the conservative scenario, exports of natural gas from the United States would decrease from the 1992 level of 250 million cubic feet per day (MMCF/d), would return to that level by 1995 , and would reach about $980 \mathrm{MMCF} / \mathrm{d}$ by 2000 . Under the more optimistic scenario, exports would decrease in 1993 and would recover and rise to about $360 \mathrm{MMCF} / \mathrm{d}$ in 1995 and to $1,920 \mathrm{MMCF} / \mathrm{d}$ in 2000.
\end{abstract}

\section{SUMMARY}

\section{INTRODUCTION}

This report contains the results of a study of the Mexican natural gas industry and of the prospects for exporting natural gas from the United States to Mexico until the end of the century. The report is based on information obtained in interviews with officials of key Mexican federal agencies and other knowledgeable Mexican authorities, as well as on information in the literature.

The study had four objectives. The first was to describe the current status of the Mexican natural gas industry. Included in this objective were descriptions of resources, production levels, the gas transport pipeline system (and points of interconnection with the pipeline system in the United States), and natural gas use broken down by economic sector. The second objective was to describe the factors that have shaped the evolution of the industry or that are expected to influence its progress until the end of the century. These factors include Mexican federal agencies and their policies, efforts to reduce environmental pollution by substituting natural gas for less environmentally benign fuels, and the proposed North American Free Trade Agreement (NAFTA). The third objective was to project production and use of natural gas through the end of the century. This period is divided into a near term (1993-1995) and an intermediate term (1996-2000). The final objective was to estimate the market for exports of natural gas from the United States to Mexico in the near 
term and the intermediate term. For the purposes of projecting future production and consumption of natural gas and for estimating the market for U.S. exports, a conservative scenario and an optimistic scenario were constructed.

\section{MEXICAN INSTITUTIONAL FRAMEWORK}

In the Mexican natural gas industry, the federal government plays a much different role than it does in the United States. In the United States, a large number of gas producers and pipeline companies exist. For the most part, producers sell gas to local, regulated-distribution public utilities that sell the gas to the end user at retail rates. Pipeline companies now only transport gas. In contrast, Mexico has a national energy monopoly (Petroleos Mexicanos [PEMEX]) that has exclusive jurisdiction over exploration, production, and refining of oil and gas; distribution of oil; transport of gas prior to first sale; and external trade in gas and oil. PEMEX also must have sole ownership of all basic petrochemical plants and . majority interest in secondary petrochemical plants. Most of the gas sold by PEMEX is sold directly to the industrial end user or to the Federal Electricity Commission (CFE), ${ }^{1}$ the federal electrical public utility; however, a few locally owned independent gas distribution companies buy gas from PEMEX and sell it at retail rates to residential, commercial, and industrial customers.

Although nothing indicates that the jurisdiction of PEMEX, which is derived from the Mexican Constitution, will be abridged, a trend exists toward increased roles for the private sector. In December 1992, the Public Service Law for Electrical Energy was reformed to permit privately owned generation and cogeneration facilities to sell electricity to CFE for resale, and CFE is negotiating with investors in two such facilities that would be fueled with natural gas (at Mérida in Yucatan and at Rosarito in Baja California). Also, the Secretariat of Energy, Mines, and Public Industry (SEMIP) is reducing the number of petrochemicals that are defined as basic and secondary. This action should encourage private investment in plants to produce the newly unrestricted petrochemicals.

Mexico has some serious environmental problems, especially air pollution in the metropolitan areas of Mexico City, Monterrey, and Guadalajara. Because natural gas is such a clean fuel, some steam-electric generating stations and industrial plants have recently been converied to natural gas. Moreover, because much of the air pollution in the metropolitan areas is caused by vehicles, government and private industry are also interested in converting vehicles to use compressed natural gas (CNG). The government of Mexico City has an ambitious program to convert its municipal bus fleet and the passenger and cargo vehicles that Mexico City licenses (more than 300,000 vehicles) to CNG; however, this program is still in the pilot stage. Conversion of vehicles to CNG by private industry faces a number of impediments. These impediments include the limited number of fueling stations, the

1 English names of Mexican governmental organizations are taken from North American Free Trade Agreement: U.S.-Mexican Trade and Investment Data (GAO 1992). Their Spanish names are given in the notation list on $\mathrm{p}$. viii. 
possibility of a tax that would eliminate price advantages at the fuel station, and the absence of regulatory standards (e.g., emission standards).

NAFTA, if ratified, is expected to help the Mexican economy and therefore increase the demand for natural gas; however, whether ratification would increase the market for gas exports from the United States is uncertain. Pursuant to Mexico's 1965 Border Industrialization Program (BIP), factories called maquiladoras were established in the Mexican states that border the United States. Under the BIP, components and materials can be temporarily imported, assembled, or processed in the maquiladoras and can be exported as a finished product to the United States. The BIP prohibits sales of the finished product in Mexico. NAFTA would open the Mexican market to the finished product but would gradually remove the export incentives. Thus, ratification of NAFTA could induce plants that previously would have located in the North ${ }^{2}$ of Mexico under the BIP to locate in the South instead. Because of the characteristics of Mexico's pipeline network, natural gas exported from the United States would be expected to be used only in the North. Most of the maquiladoras are in industries that do not need process heat and therefore are not large direct users of natural gas; however, the industries do use significant amounts of electricity, and, if they locate plants in the South, the demand for electricity from gas-fired generating stations in the North, which often use gas exported from the United States, likely would be reduced.

\section{RESOURCES AND PRODUCTION}

Mexico's current proven natural gas reserves stood at 70.9 trillion cubic feet (TCF) in 1991, compared with 169.5 TCF in the United States and 96.5 TCF in Canada. In addition, unproven Mexican reserves are estimated at 180 TCF. The reserves in the three PEMEX administrative districts are 36.6 TCF in the North Region, 23.2 TCF in the South Region, and 11.1 TCF in the Marine Region (Figure S.1). Eighty-three percent of the proven natural gas reserves are associated with crude oil. Much of the nonassociated gas is in the North Region in a basin at Reynosa, Tamaulipas, across the U.S. border at the southern tip of Texas.

Reserves have declined by approximately $10 \%$ over the last 10 years. Production has also declined: it peaked in 1982 at 1,548 billion cubic feet (BCF) $(4,240$ million cubic feet per day [MMCF/d]) and has declined since then, reaching 1,312 BCF/yr (3,620 MMCF/d) by 1992. Overall, the ratio of reserves to production has not changed significantly. Although more than half of the proven reserves are in the North Region, nearly $90 \%$ of the production is from the South and Marine regions. Production is higher from these regions mainly because production there yields both natural gas and crude oil, and the cost allocated to natural gas

2 In this report, "the North" refers to the six states that border the United States (Tamaulipas, Nuevo León, Coahuila, Chihuahua, Sonora, and Baja California), plus Durango. The rest of Mexico is referred to herein as "the South." A map of Mexico indicating these six states and the gas production regions appears as Figure S.1. 


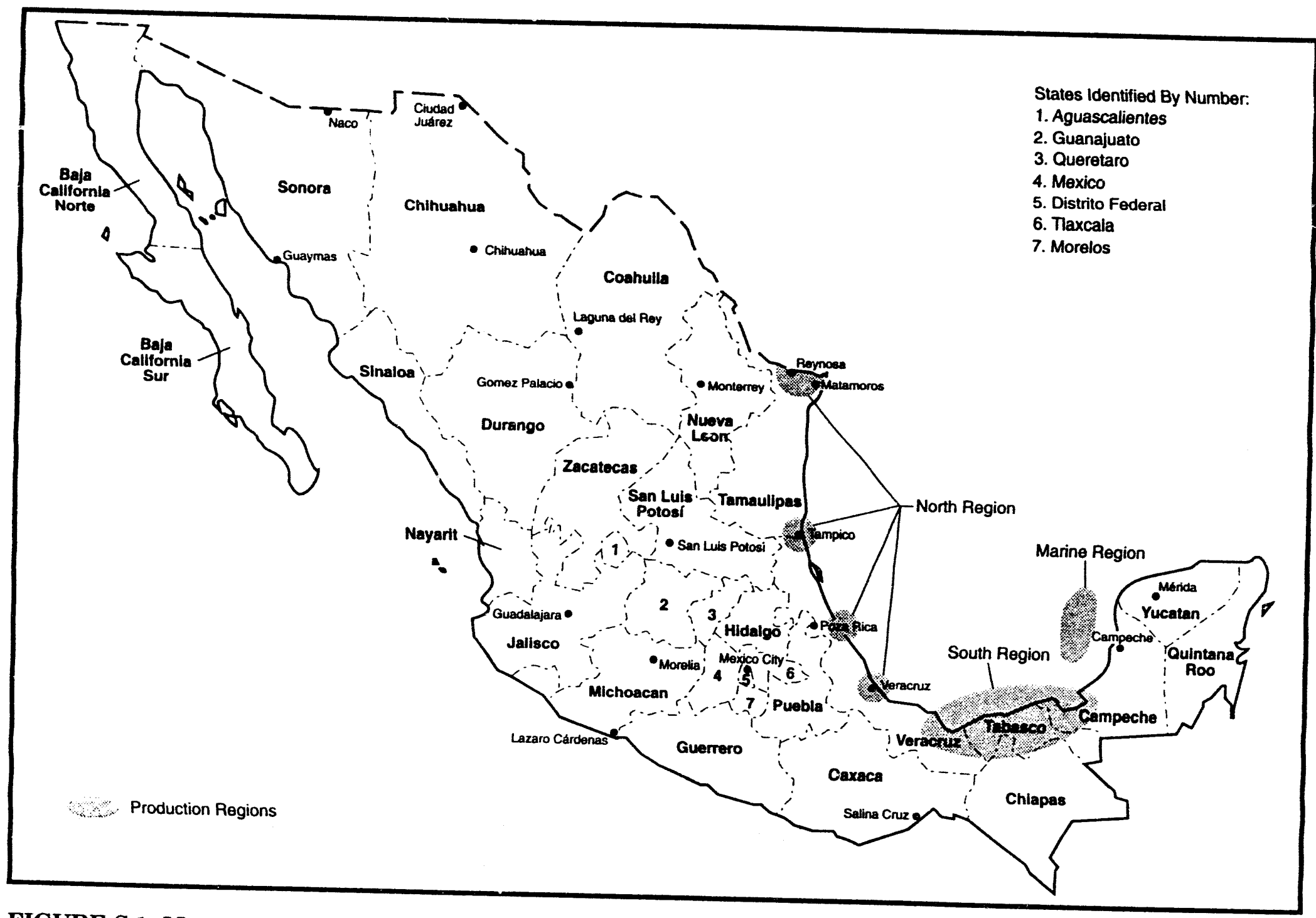

FIGURE S.1 Map of Mexico Showing Gas Production Regions 
for exploration and production is lower ( $\$ 1.14 /$ thousand cubic feet $[\mathrm{MCF}]$ for nonassociated gas; $\$ 0.25 / \mathrm{MCF}$ for associated gas).

\section{CONSUMPTION BY SECTOR}

Consumption of natural gas in Mexico can be divided into five sectors: (1) PEMEX production of petrochemicals, (2) industrial (non-PEMEX) use, (3) electrical generation, (4) residential and commercial use, and (5) transportation. Historically, no consumption has occurred in the transportation sector.

The PEMEX petrochemical plants have been the largest users of natural gas in Mexico. Over the past seven years (Table S.1), their consumption of dry gas has fluctuated within a narrow range near $1,100 \mathrm{MMCF} / \mathrm{d}$, or approximately $50 \%$ of the total produced in Mexico. As part of its reorganization, PEMEX is reviewing the profitability of its petrochemical enterprises. Production of ammonia is one of the first operations to be affected. About 25\% of Mexico's ammonia production was exported in 1992, and, as a result of a decline in world prices for ammonia, PEMEX no longer considers such exports to be profitable. In 1992 and in the first quarer of 1993, two facilities producing ammonia were closed, and several were shut down temporarily.

Historically, the industrial sector (excluding PEMEX) has been the second largest user of natural gas, accounting for more than one-third of the gas delivered via the pipeline system. Six major industries - iron and steel, chemicals, cellulose and paper, mining, glass, and food - accounted for $83 \%$ of the total industrial usage in recent years. Although consumption of natural gas in the industrial sector also fluctuated in a narrow range (approximately 700-800 MMCF/d) during the last half of the 1980s, a significant increase of about $10 \%$ occurred during the past two years. Much of the increase is occurring in the North of Mexico, and this increased demand is largely being met by imports from the United States.

The CFE began operation of energy-efficient, gas-fired combined-cycle plants with two units in 1975. Since 1985, the seven combined-cycle units presently in operation at five locations (Huinala, Gómez Palacio, Tula, Dos Bocas, and El Sauz) have consumed natural gas in the range of 285-300 MMCF/d. The CFE also began repowering oil-fired steam stations to natural gas to improve air quality in urban centers. Steam plants in the Valley of Mexico and in the North were converted in 1990 and 1991, respestively, raising the total consumption by CFE by approximately $45 \%$ to the 1991 average of $441 \mathrm{MMCF} / \mathrm{d}$. Officials of the CFE have indicated that gas supplies to generating stations in the North were limited in the latter part of 1992 and continue to be limited in 1993. The program of converting oil-fired generating stations to natural gas created a demand for natural gas that has been a major factor in the increase of exports to Mexico from the United States.

An estimated 3,000 megawatts (electric) (MWe) is currently being produced by cogeneration, chiefly in the oil, petrochemical, steel, sugar, chemical, and paper industries (DOC 1992); however, until the recent reform of Mexico's Public Service Law for Electrical 
Energy, privately owned electrical generation facilities and cogeneration facilities were not permitted to sell electricity to the CFE. Now the CFE is planning to purchase electricity from two major, privately owned, gas-fired facilities that are independent power producers (IPPs), which are to be located at Mérida in Yucatan and at Rosarito in Baja California.

Natural gas is used in the residential/commercial (domestic) sector for hot water heating and for cooking. Gas for this sector is provided by local gas distribution companies that buy wholesale from PEMEX, transport the gas in pipelines that they own, and sell the gas at retail rates. The relatively small amount (85-90 MMCF/d) of gas provided by these local gas distribution companies has shown little change in the past five years. Eleven gas distribution companies currently serve an estimated 600,000 customers, and five new companies have been established but are not yet operating. The smaller companies serve predominantly residential and commercial customers, while the larger distribution companies serve large industrial customers as well.

Although, historically, no consumption of natural gas has occurred in the transportation sector, conversion of vehicles to natural gas is seen as a way to improve air quality in congested urban areas such as Mexico City and Monterrey. The government of Mexico City has an ambitious program for converting vehicles to liquefied petroleum gas or CNG in metropolitan Mexico City. In all, the program calls for the conversion of nearly 330,000 vehicles, licensed public service taxis, minibuses, buses, cargo trucks, garbage trucks, and other municipal vehicles. The Mexico City program is now in the pilot stage. Approximately 50 vehicles have been converted to date, and one fueling station has been established. In Monterrey, the Monterrey Institute of Technology and Higher Education operates one vehicle fueled by liquefied natural gas as part of a research program; however, Monterrey has no municipal program as yet. Although considerable interest exists in the private sector among manufacturers of conversion products, investing in CNG vehicles is restricted by serious governmental impediments (e.g., emission standards have not yet been promulgated) at this time.

In summary, total consumption of natural gas in Mexico has risen about $10 \%$, from 2,218 MMCF/d in 1986 to 2,487 MMCF/d in 1992. Detailed year-by-year data can be found in Table 2.3 in the main body of the report.

\section{FUTURE PRODUCTION AND CONSUMPTION OF NATURAL GAS}

Production and consumption of natural gas in Mexico have been projected by means of two scenarios (Scenarios A and B) for the period 1993-2000. The projections under both scenarios cover the near term (1993-1995) and the intermediate term (1996-2000). The two scenarios differ in the degree to which environmental considerations are assumed to stimulate the demand for natural gas, in the dates when new gas-fired electrical generating stations will come on-line, and in the degree to which PEMEX will supply gas to meet the demand. Scenario A is based on conservative assumptions; Scenario B is based on more optimistic assumptions that would result in greater use of natural gas. For exanple, the recent rate of growth of the Mexican economy has been 3\% annually, and growth is expected 
to continue at that rate for the immediate future. Scenario A assumes a $3 \%$ annual increase in the industrial use of natural gas to keep pace with the economy. Scenario B assumes a 4.5\% annual increase in the industrial use of natural gas. This latter rate of growth, which is greater than that of the general economy, is representative of the increases in industrial gas use during the last two years. The assumptions used in the projections of consumption are discusse $\mathbb{d}$ subsequently.

\section{Projection of Production}

The officials of SEMIP and PEMEX interviewed by the authors in May 1993 agreed that production of natural gas in the immediate future would continue the trend set in the immediate past, that is, a trend of steady to slightly decreased production. The reasons given for maintaining this trend include the continuing tightness of available capital and a concern that major capital expenditures by PEMEX could have an inflationary effect on the economy. Any expenditures for new exploration and production are expected to be for efforts in the South and Marine regions, because profitable crude oil will be produced there, as well as natural gas. Thus, for both scenarios, production in the North Region is assumed to continue to decline, and production in the South and Marine regions is assumed to increase to the extent that total production is maintained at or near the 1992 level.

\section{Projection of Consumption by Sector}

Projections for demand were made for five sectors by using sector-dependent assumptions. These sectors are (1) PEMEX petrochemicals, (2) industrial (non-PEMEX) use, (3) electrical generation, (4) residential and commercial use, and (5) transportation.

Consumption by PEMEX petrochemical plants can be expected to decrease in the near term as unprofitable plants are closed, but usage in other PEMEX petrochemical plants is expected to keep pace with the economy. We assume that these two effects cancel each other and that consumption by PEMEX plants is flat at 1,070 MMCF/d from 1993 through 1995. (This value represents an initial drop of $51 \mathrm{MMCF} / \mathrm{d}$ from the 1992 level.) By 1995, the closure of unprofitable plants should be completed. Thereafter, consumption by the remaining plants would grow in parallel with the Mexican economy (i.e., at 3\% annually).

Gas usage in the industrial sector, excluding PEMEX, is assumed to increase by $3 \%$ annually in Scenario A and by $4.5 \%$ annually in Scenario B. As discussed previously, most maquiladoras do not use process heat; consequently, their direct impact on natural gas usage is small, and their indirect impact would consist of using electricity generated by natural gas.

In the electrical sector for the near term (1993-1995), no new conversions of existing oil-fired electrical generating plants are planned; however, construction of a new 700-megawatt (MW) combined-cycle station, Samalayuca II (located about $30 \mathrm{mi}$ south of Ciudad Juárez), is now under contract to a consortium. Samalayuca II will be fueled by gas imported from the United States, and a new pipeline will be constructed by the consortium 
(and will be owned by PEMEX) as part of the project. The first unit is scheduled for completion in late 1995.

In the intermediate term (1996-2000), two major gas-fired generating projects are planned. These privately owned IPP projects will sell electricity to CFE, pursuant to the recent changes in the public service law. These IPPs will be located at Mérida in Yucatan and at Rosarito in Baja California. The Mérida plant would come on-line after 1995 and would require natural gas at up to $125 \mathrm{MMCF} / \mathrm{d}$ to be supplied from domestic sources. The plant at Rosarito would be built in stages, but no decision has been reached on the schedule and final size. In addition, the existing oil-fired plant at Rosarito would be converted to gas. Planning for the gas supply is based on importing natural gas at up to $250 \mathrm{MMCF} / \mathrm{d}$, because using Mexican gas would require construction of a 1,000-mi-long pipeline. Two alternatives are being considered for importing the gas: in one, the gas would come directly from southern California; in the other, gas would come through a new 150-mi-long pipeline to be constructed south of the U.S. border from Yuma, Arizona.

Under Scenario A, PEMEX would continue to limit the supply of domestic gas to plants in the North for both the near and intermediate terms, and no new plants would be built or converted in the near term. In this scenario, the s'atus of the three new gas-firet plants in 2000 is assumed to be as follows: Samalayuca II, on-line and operating at full capacity; and the Mérida and Rosarito plants, operating at half capacity. Under Scenario B, PEMEX would supply sufficient gas to run present CFE plants at their optimal ratings, and the three new plants would run at full capacity in 2000 .

Little or no increase in consumption in the residential/commercial sector is projected for the near term. Growth in the intermediate term is expected to be slow but steady, with the five new local distribution pipelines beginning operation. In Scenario A, these conditions are assumed to result in an increase in natural gas use of 90-95 MMCF/d in 1995 and $110 \mathrm{MMCF} / \mathrm{d}$ in 2000. Under Scenario B, in which the Mexican government is assumed to aggressively encourage natural gas use in this sector, usage is assumed to double by 2000 . This assumption reflects the most optimistic prospect indicated by the president of the Mexican Gas Association.

Substantial use of natural gas in the transportation sector is unlikely by 2000 , unless the Mexican government acts to remove existing impediments and to provide incentives. In Scenario A, efforts to use natural gas as a fuel in transportation would fail as a result of some combination of regulatory uncertainties, taxes, and inadequate infrastructure. In Scenario $B$, the assumptions are made that these impediments would be gradually removed and that the Mexico City program would be fairly successful, so that by 2000, about 100,000 CNG-powered vehicles would be in use.

In summary, under Scenario A, only a small increase in the total 1995 consumption by non-PEMEX users over 1992 levels is projected. That increase would be offset by the decrease in consumption by PEMEX petrochemical facilities; however, by 2000 , a $50 \%$ increase in consumption by non-PEMEX users is projected, supplemented by a $10 \%$ increase by PEMEX petrochemicals. Details are given in Table 3.1 in the main body of the report. 
. Under Scenario B, consumption by non-PEMEX users in 1995 is projected to increase about $10 \%$ over 1992 levels and is projected to more than double by 2000. PEMEX petrochemical consumption would follow that projected in Scenario A.

\section{ESTIMATES OF THE MARKET FOR U.S. EXPORTS}

For several years, PEMEX has purchased natural gas from the United States to make up the difference between what PEMEX supplies to non-PEMEX users and what remains from domestic production after the needs of PEMEX facilities have been met. Table S.1 gives projections of the annual exports of gas (units given in table) from the United States. These projections are based on the assumption that Mexico continues to purchase natural gas from the United States for the immediate future.

TABLE S.1 Projections of U.S. Exports of Natural Gas to Mexico, 1993-2000

\begin{tabular}{|c|c|c|c|c|c|c|c|}
\hline \multirow[b]{3}{*}{ Sector } & \multicolumn{7}{|c|}{ Natural Gas (MMCF/d) } \\
\hline & \multirow[b]{2}{*}{$1992^{\mathrm{a}}$} & \multicolumn{3}{|c|}{ Scenario A } & \multicolumn{3}{|c|}{ Scenario B } \\
\hline & & 1993 & 1995 & 2000 & 1993 & 1995 & 2000 \\
\hline Production & 2,237 & 2,237 & 2,237 & 2,237 & 2,237 & 2,237 & 2,237 \\
\hline $\begin{array}{l}\text { PEMEX petrochemical } \\
\text { consumption }\end{array}$ & 1,121 & 1,070 & 1,070 & 1,240 & 1,070 & 1,970 & 1,240 \\
\hline $\begin{array}{l}\text { Available for other domestic } \\
\text { users }^{\text {b }}\end{array}$ & 1,116 & 1,167 & 1,167 & 997 & 1,167 & 1,167 & 997 \\
\hline $\begin{array}{l}\text { Total consumption by } \\
\text { non-PEMEX users }\end{array}$ & 1,366 & 1,374 & 1,433 & 1,975 & 1,404 & 1,529 & 2,817 \\
\hline U.S. exports ${ }^{c}$ & $250^{\mathrm{d}}$ & 207 & 256 & 978 & 237 & 362 & 1,920 \\
\hline
\end{tabular}

a Data from PEMEX (1992a, p. 164).

b Difference between dry gas production delivered to pipelines and consumption in PEMEX petrochemical facilities.

c Difference between total consumption by non-PEMEX users and supplies available to those users from indigenous sources.

d This value is from PEMEX (1992a, p. 164); however, U.S. sources (DOE 1992) indicate a value of $260 \mathrm{MMCF} / \mathrm{d}$. The difference may be the result of different methods of measurement. Where calculations are based on references to Mexican data, the value of $250 \mathrm{MMCF} / \mathrm{d}$ has been used. 
As shown in Table S.1, U.S. exports will drop in 1993. This drop can be attributed to the fact that additional gas will be made available to non-PEMEX users by the recent closing of the ammonia plants; however, by 1995, U.S. exports would return to the 1992 level in Scenario A and would rise above the 1992 level (to $362 \mathrm{MMCF} / \mathrm{d}$ ) in Scenario B. Beyond 1995, U.S. exports should increase to help supply the requirements of the Samalayuca II and Rosarito projects. In addition, the demand for exports from the United States should increase because PEMEX will be providing less gas to non-PEMEX users as use in its own facilities parallels the growth in the Mexican economy. Finally, U.S. exports would also increase to help supply the additional gas needed to support overall growth of the Mexican economy. Under Scenario A, these exporis would rise to $978 \mathrm{MMCF} / \mathrm{d}$ in 2000; under Scenario B, exports would reach 1,920 MMCF/d.

Operations by PEMEX are and have been an important positive element in Mexico's balance of payments, contributing $\$ 7-9$ billion (U.S. dollars) to that balance annually in the early 1990s. The increased imports would cut into that favorable balance by 2000 . At today's prices, the cost in 200 would be $\$ 680$ million for Scenario A and $\$ 1,338$ million for Scenario B. If this cost is perceived as being too high, PEMEX might take steps to reduce imports of natural gas: PEMEX could increase exploration and production or further curtail the supply to non-PEMEX users.

The assumption has also been rade that all Mexican imports of natural gas are from the United States. Canada is also interested in exporting gas to Mexico. In fact, one of the alternatives for the gas supply for the Rosarito electrical generating plant calls for the use of Canadian gas, which would be shipped through California. Thus, some of the gas exported to Mexico from the United States might be of Canadian origin.

\section{CONCLUSIONS}

Exports of natural gas from the United States to Mexico during the forecast period have been estimated by assuming that Mexican production remains at the 1992 level and that consumption follows one of two scenarios, the conservative Scenario A or the optimistic Scenario B. For the conservative scenario, exports of natural gas from the United States would drop from the 1992 level of $250 \mathrm{MMCF} / \mathrm{d}$ but would return to that level by 1995 . Under that scenario, U.S. exports to Mexico would rise to about $980 \mathrm{MMCF} / \mathrm{d}$ in 2000 . Under the optimistic scenario, U.S. exports to Mexico would fall in 1993 but would recover and rise to $362 \mathrm{MMCF} / \mathrm{d}$ in 1995 and to $1,920 \mathrm{MMCF} / \mathrm{d}$ in 2000.

The present gas pipelines, both at the border crossings and within the Mexican pipeline system, have the capacity to transport the projected increased quantities of gas for the near term. With the addition of a pipeline for the Samalayuca II project and one of the pipelines proposed for the Rosarito project, the pipeline system should be able to transport the quantities needed for 2000 .

However, the projected increases in exports may not be reached if PEMEX invests in increased indigenous gas production or increasingly limits the amounts of gas PEMEX 
makes available to non-PEMEX users. It might choose to do either of these if the cost of the projected imports were to increase. 


\section{BACKGROUND}

\subsection{OBJECTIVES AND ORGANIZATION OF THIS REPORT}

This report contains the results of a study of the Mexican natural gas industry. The study had four objectives. The first was to describe the current status of the Mexican natural gas industry. Included in this objective were descriptions of resources, production levels, the gas transport pipeline system, and use broken down by economic sector. The second objective was to describe the factors that have shaped the evolution of the industry or that are expected to influence its progress until the end of the century. These factors include Mexican federal agencies and their policies, efforts to reduce environmental pollution, and the proposed North American Free Trade Agreement (NAFTA). The third objective was to project production and use of natural gas to the end of the century. This period is divided into a near term (1993-1995) and an intermediate term (1996-2000). The final objective was to estimate the market for exports of natural gas from the United States to Mexico in the near term and the intermediate term. For the purposes of projecting future production and consumption of natural gas and for estimating the market for U.S. exports, a conservative scenario and an optimistic scenario were constructed.

This report is divided into four main sections and an appendix. The remainder of Section 1 describes the factors that shape the Mexican natural gas industry. Section 2 describes the Mexican natural gas industry (resources, production, consumption, and pipelines). Section 3 contains estimates of future production and consumption that are based on the conservative and optimistic scenarios. Section 4 contains estimates of the market for U.S. natural gas that are based on the two scenarios. The Appendix contains organizational information about Mexican federal agencies.

\subsection{INSTITUTIONAL FRAMEWORK OF NATURAL GAS TRADE WITH MEXICO}

The institutional framework within which the Mexican gas industry operates is quite different from that in the United States. For example, a public entity has a monopoly on production in Mexico, in contrast to the United States, where a large number of private producers exist. Therefore, we will briefly describe the Mexican institutional framework. Most natural gas production in Mexico is associated with crude oil production, so the gas industry in Mexico is closely linked with the oil industry. The history of the Mexican oil industry is a key factor that will be described. Also, this section provides an introduction to the Mexican governmental organizations whose policies affect the demand for natural gas, as well as a discussion of the maquiladoras - factories that have been established in Mexico in response to incentives from Mexico and favorable U.S. tariff provisions. 


\subsubsection{History of the Mexican Oil Industry}

The Mexican oil industry has been characterized as having undergone three phaces (Foran 1991). The first phase extended from 1900 to 1938. During that period, Mexico's oil and gas resources were explored and developed by independent and multinational companies, and oil production increased rapidly. In 1921, Mexican oil production averaged 500,000 barrels per day, second only to the United States.

The second phase began abruptly in 1938, when the Mexican government, under the Cardenas administration, expropriated all of the holdings of foreign oil companies and nationalized the oil and gas industry. Article 27 was added to the Mexican Con titution, specifically prohibiting all foreign investment in oil and gas exploration and development (NPC 1992). The state oil company that emerged is Petroleos Mexicanos (PEMEX). Mexican oil production fell during this phase, while domestic oil demand increased. By 1957, Mexico was importing oil to meet domestic demand. This drop in production has been attributed to the isolation from international capital and technical expertise that resulted from nationalization (Foran 1991).

The third phase began with the first international oil crisis in 1973-1974 and the accompanying increase in world oil prices, which caused PEMEX to initiate large-scale exploration that was financed mostly by foreign loans. These explorations led to large additions to the nation's known reserves and to greatly increased oil production, which peaked in 1982 at an average of 3 million barrels per day. The combination of softening oil prices in the mid-1980s and rising interest rates on the foreign loans resulted in a severe debt crisis. The de la Madrid administration, which immediately preceded the current Salinas administration, decided to honor its foreign debt. As a consequence of this decision and the continuing low world oil prices, PEMEX has not had sufficient capital to make significant investments in exploration, development, and infrastructure.

The United States and Mexico have traded in natural gas since shortly after the Second World War. Imports from Mexico peaked during the early 1980s, when Mexican oil production peaked. In November 1984, when gas and oil prices started to decline, Mexico stopped exporting natural gas to the United States. Since then, a trend of increasing U.S. gas exports to Mexico has been seen. This natural gas trade is discussed in greater detail in Section 2.

\subsubsection{Agencies Whose Policies Impact Natural Gas Production and Consumption}

The United Mexican States ("Mexico") is a federal republic consisting of 31 states and the Federal District, which is conterminous with Mexico City. A map of Mexico is included as Figure 1.1. An organizational chart showing the cabinet-level secretariats in the Mexican executive branch is given in Figure A.1 of the Appendix. Mexican federal organizations having the greatest impact on the development of the gas industry are described in the following paragraphs. 


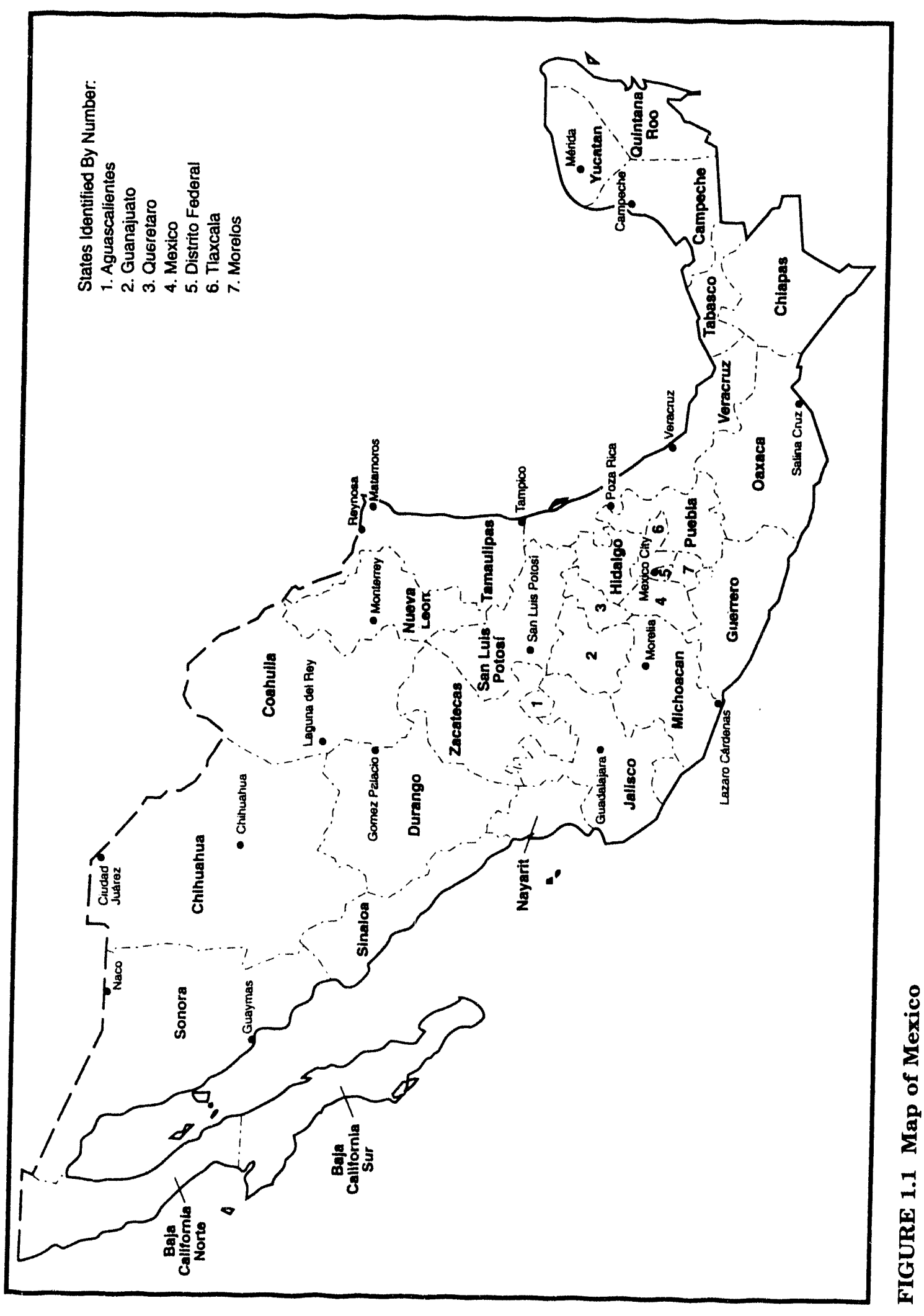


The Secretariat of Energy, Mines, and Public Industry (SEMIP) ${ }^{3}$ is responsible for overall energy policy in Mexico. SEMIP's recent five-year plan for 1990-1994 recognizes the importance of natural gas. As reported by the National Petroleum Council (NPC 1992), this plan contains the following elements:

- Modernize the energy price structure by reducing hydrocarbon subsidies on domestic sales.

- Spread the fiscal burden of development across all fuels by reducing some of oil's current preferential treatment.

- Target dry-gas production at 3.3-3.4 billion cubic feet per day (BCF/d) by 1994 (from about $3 \mathrm{BCF} / \mathrm{d}$ currently).

- Establish an exploration and production program focused on natural gas.

- Increase the use of natural gas in "environmentally high priority" activities such as electric power generation.

- Reduce PEMEX's use of natural gas as fuel, especially within the petrochemical industry, thus making more gas available for the power generation sector.

SEMIP has undergone substantive changes since January 1, 1993, including changes in personnel, when Dr. Emilio Lozoya Thalmann was appointed Secretary. He created a new post of Undersecretary for Regulation in April; Saivador Giordano was appointed to this post. The post of Undersecretary for Energy is now held by Ing. Alfredo Elias Ayub, who was formerly Undersecretary for Mines. That post is now held by Ing. Carlos Pérez García. The key post of Director of Energy Policy is now held by Lic. Mauricio Toussaint. One agency associated with SEMIP is the Mexican Petrochemical Commission (CPM), which regulates certain environmental aspects of the petrochemical industry. An organization chart for SEMIP is shown in Figure A.2 of the Appendix.

Mexican Petroleum (PEMEX) is the primary organization that implements SEMIP's hydrocarbon policy. PEMEX is the national monopoly that has exclusive jurisdiction over exploration, production, and refining of oil and gas; distribution of oil; transport of gas prior to first sale; and external trade in gas and oil. Petrochemicals are divided into three classes: basic, secondary, and unrestricted. Under Article 27 of the Mexican Constitution, PEMEX must have sole ownership of all basic petrochemical plants and a majority interest in all secondary petrochemical plants (the interests of private and foreign capital cannot exceed $40 \%$ ). Unrestricted petrochemical plants do not have ownership restrictions (SEMIP 1992).

3 English names of Mexican government agencies are taken from North American Free Trade Agreement: U.S. - Mexican Trade and Investment Data (GAO 1992). Their Spanish names are given in the notation list on p. viii. 
In recent years, CPM has reduced the number of petrochemicals in the basic and secondary classes. In 1986 , there were 34 basic chemicals and 36 secondary chemicals. The reclassification in 1989 reduced the number of basic petrochemicals to 19 , but increased the number of secondaries to 67 . Following the reclassification of 1992,8 basic petrochemicals and 13 secondary petrochemicals are recognized (Table 1.1).

PEMEX is a very important entity in Mexico. PEMEX is the largest employer in the country, and its sales and assets account for 30\% of the national government's annual revenue (NPC 1992). PEMEX has recently undergone a complete reorganization to make it a more efficient business organization. This reorganization included spinning off some of its social service programs and forming five operating subsidiary companies. The five operating subsidiaries are (1) PEMEX Exploration and Production, (2) PEMEX Refining, (3) PEMEX Gas and Basic Petrochemicals, (4) PEMEX Petrochemicals, and (5) PEMEX International (PMI). Their missions are given in Table 1.2.

The Federal Electricity Commission (CFE), a national government monopoly associated with SEMIP, has jurisdiction over generation and distribution of electricity for public use. The CFE can be considered as analogous to a federally owned public utility. The CFE does not own all of the electrical generating stations in Mexico. PEMEX and some other large enterprises operate cogeneration plants that produce thermal energy and electricity for their internal use.

On December 23, 1992, Mexico amended its Public Service Law for Electrical Energy (Official Diary 1992). These amendments allow privately owned entities to sell electricity to the CFE. The types of entities are independent power producers (IPPs) (e.g., a generating station whose primary purpose is to sell electricity to CFE); self-generators (e.g., an industrial plant that primarily produces electricity for internal use and sells any excess to CFE); cogenerators (i.e., facilities that jointly produce electricity and useful thermal energy); and small power producers (e.g., generating stations with a capacity of less than 30 megawatts [electric] [MWe]). The amendments also authorized SEMIP to establish an energy regulatory commission to facilitate achieving the objectives of the amendments. SEMIP published regulations to implement these amendments on May 31, 1993 (Official Diary 1993). The CFE plans to purchase electricity from gas-fired IPP plants at Mérida in Yucatan and at Rosarito in Baja California. Promulgation of these regulations should remove uncertainties and facilitate CFE's negotiations with investors in these proposed projects. Figure A.3 of the Appendix is an organization chart for CFE.

The Secretariat of the Treasury and Finance (Secretaria de Hacienda y Credito Publico) is responsible for tax policy and proposals. Taxation of natural gas that could affect its attractiveness as a fuel is an important issue that this group will address. The Secretary of the Treasury will likely propose a tax on compressed natural gas (CNG) that will reduce or eliminate the retail price advantage of CNG over gasoline or diesel fuel. The regulations implementing the amendments to the Public Service Law for Electrical Energy give the Secretariat of the Treasury and Finance the primary role in developing rates for the sale of electricity to the CFE. 
TABLE 1.1 Classification of Petrochemicals

\begin{tabular}{ll}
\hline $\begin{array}{c}\text { Basic } \\
\text { Petrochemicals }\end{array}$ & $\begin{array}{c}\text { Secondary } \\
\text { Petrochemicals }\end{array}$ \\
\hline Ethane & Acetylene \\
Propanes & Ammonia \\
Butanes & Benzene \\
Pentanes & Butadiene \\
Heptanes & Butylene \\
Hexanes & Ethylene \\
Feedstock for & Methanol \\
carbon black & $n$-Paraffin \\
Naphtha & $o$-Xylene \\
& $p$-Xylene \\
& Propylene \\
& Toluene \\
& Xylene \\
\hline
\end{tabular}

Source: SEMIP (1992).

TABLE 1.2 Operating Subsidiaries of PEMEX

\begin{tabular}{|c|c|}
\hline Operating Subsidiary & Responsibilities \\
\hline $\begin{array}{l}\text { PEMEX Exploration } \\
\text { and Production }\end{array}$ & $\begin{array}{l}\text { Responsible for all exploration and production activities within } \\
\text { Mexico, as well as all field-gathering pipelines and crude export } \\
\text { facilities. }\end{array}$ \\
\hline PEMEX Refining & $\begin{array}{l}\text { Responsible for the supply and marketing of all refined products } \\
\text { within Mexico; owns and operates } 6 \text { refineries, more than } 85 \text { refined- } \\
\text { product distribution terminals, gasoline stations, and crude-product } \\
\text { pipelines for FEMEX. }\end{array}$ \\
\hline $\begin{array}{l}\text { PEMEX Gas and } \\
\text { Basic Petrochemicals }\end{array}$ & $\begin{array}{l}\text { Responsible for the supply and marketing of liquefied petroleum gas } \\
\text { (LPG), natural gas, and basic petrochemicals; will own and operate } \\
\text { PEMEX's gas plants, LPG pipelines and distribution terminals, and } \\
\text { natural gas pipelines, as well as all the PEMEX basic petrochemical } \\
\text { plants. }\end{array}$ \\
\hline $\begin{array}{l}\text { PEMEX } \\
\text { Petrochemicals }\end{array}$ & $\begin{array}{l}\text { Owns and operates all PEMEX secondary petrochemical facilities } \\
\text { and markets their products to Mexico's private sector. }\end{array}$ \\
\hline $\begin{array}{l}\text { PEMEX } \\
\text { International }\end{array}$ & $\begin{array}{l}\text { Markets crude oil exports; conducts international trading in natural } \\
\text { gas, oil products, and chemicals; and manages PEMEX's foreign } \\
\text { holdings. }\end{array}$ \\
\hline
\end{tabular}

Source: Lajous (1992). 
The Secreiariat of Trade and Industrial Development (SECOFI) is the equivalent to the Department of Commerce in the United States. A permit from SECOFI is required if a local gas distribution company wants to establish or extend a system or if a company wants to sell equipment for converting vehicle engines to natural gas use. SECOFI also plays a secondary role in the development of rates for sales of electricity to CFE under the amendments to the Pubiic Service Law for Electrical Energy.

The Secretariat of Social Development (SEDESOL) is now the agency responsible for promulgating and enforcing environmental regulations. As such, SEDESOL is the successor to the Secretariat of Urban Development and Ecology (SEDUE). SEDESOL is not adapting environmental regulations from the United States, but rather is developing its regulations independently. Among the regulations that have not been issued as yet are those setting emission standards for vehicles using natural gas and those setting hazardous waste standards.

States and municipalities have some authority over local gas distribution companies and vehicles. Local gas distribution companies must obtain a permit from a local government to lay distribution pipe under public rights-of-way. This permit is analogous to a franchise that a gas distribution public utility would obtain from a municipality in some states in the United States. States and municipalities in Mexico could potentially use their licensing authority over taxis, jitneys, private bus companies, and truck companies to encourage the use of CNG in vehicles. Governments could also convert their vehicles to CNG.

\subsubsection{Maquiladora Program}

In 1965, Mexico established the Border Industrialization Program (BIP). This program permits components made in the United States to be temporarily imported on an in-bond, duty-free basis. The components are then assembled or processed in Mexico and exported to the United States in-bond as assembled products (Perry et al. 1990). Under U.S. tariff regulations, the finished or semifinished products are subject to duty only on the value added by the manufacturing process. The plants that have been sited in Mexico because of the BIP and U.S. tariff regulations are known as maquiladoras. Most of these plants (more than 90\%) have located in the Mexican states that border the United States (Tamaulipas, Nuevo León, Coahuila, Chihuahua, Sonora, and Baja California). These states, together with Durango, will be referred to collectively as the "North of Mexico" or the "North" in this report. T.ee rest of Mexico is referred to herein as "the South" (Figure 1.1).

From the start of the program in 1965 until 1982, the number of plants grew from 12 to approximately 550 (Perry et al. 1990). Between 1982 and 1991, after the devaluation of the peso in 1982, the number of maquiladoras more than douhled to more than 1,900. One-third of the maquiladoras are $100 \%$ U.S. owned, and another $13 \%$ are majority U.S. owned. According to a U.S. firm that monitors the maquiladora industry, as much as $85 \%$ of the maquiladora work force is employed in the $100 \%$-U.S.-owned plants (GAO 1992). 
Those maquiladoras that locate near the U.S.-Mexico border are good prospects to be direct end users of natural gas, if they need process heat; however, data compiled by the National Institute of Statistics, Geography, and Information (INEGI) of Mexico indicate that most of the maquiladoras are in industrial sectors that have little or no need for process heat. For example, in 1991, nearly $70 \%$ of the maquiladoras were in the following sectors: textiles; furniture; transportation equipment; electronic and electrical equipment and parts; and service. Only about 5\% of the plants were in the chemical sector (GAO 1992). Because relatively few maquiladoras would be expected to have a significant need for process heat, the effect of the maquiladoras on the market for gas exported from the United States would likely be more strongly related to their demand for electricity than to their demand for process heat.

\subsection{ENVIRONMENTAL IMPACTS}

Mexico has some serious environmental problems. Serious air pollution exists in Mexico City and in other large cities in the valleys of the central highlands. The air pollution in Mexico City is severe enough to be life threatening. Another problem that has received much attention recently is transborder hazardous-waste and air pollution that has been attributed to the maquiladoras (Perry et al. 1990; Foy 1992). Concern about such transborder pollution in the United States may result in modification of the environmental provisions of NAFTA or may affect its congressional approval.

Concern about such environmental problems prompted Mexico to enact a comprehensive environmental law ("General Law of Ecological Equilibrium") in 1988. Regulations that fully implement this law have not yet been issued by the responsible environmental agency. Information exists showing that the difference in the stringency or enforcement of environmental laws between Mexico and the United States is a key factor in the decision of some manufacturers to relocate in Mexico. In a U.S. General Accounting Office survey of wood furniture manufacturers from the Los Angeles area that relocated to Mexico between 1988 and 1990,78\% of the respondents indicated that stringent air pollution emission control standards for paint coatings and solvents were a major factor in the decision to relocate. (The other major factor was the cost of labor.) At that time, Mexico had not established air pollution standards for paint coatings and solvents (GAO 1991). Evidence exists, however, that enforcement of the comprehensive environmental law has begun. In 1990, SEDUE ordered the temporary closing of 58 plants in the Mexico City area. In 1991, SEDUE ordered the temporary closing of 91 plants in the Mexico City area and 65 plants in other states. Of these 65 plants, 22 plants were located in states along the U.S. border ( 4 in Tamaulipas, 2 in Nuevo León, 2 in Coahuila, 3 in Chihuahua, 3 in Sonora, and 8 in Baja California) (Embassy of Mexico 1991). Because the degree to which Mexico enforces its environmental laws is a key factor in the decision of some U.S. firms to locate plants in Mexico, stricter enforcement of Mexico's environmental laws could inhibit future foreign investment in industrial plants in Mexico.

In addition to environmental regulation, the Salinas administration has funded several measures to reduce air pollution in the Mexico City area, including measures that 
rely on increased use of natural gas. In February 1992, the Mexican government announced plans to convert 450,000 public transportation and cargo vehicles to natural gas over the succeeding four years, and CFE plans to switch all fossil-fuel power plants in Mexico City to natural gas (White 1992). The vehicle conversion program includes the ambitious program of Mexico City, which is described in Section 2.3.5.

Mexico's commitment to reducing air pollution, combined with the paucity of development capital and the location of most of Mexico's developed gas reserves in the southern isthmus area, has resulted, according to commentators in the United States such as the National Petroleum Council, in the establishment of a "North-South" natural gas policy that can be expected to prevail for the near future. According to these commentators, this policy results in most of the indigenous production being directed toward meeting the demand that he . been increasing, in part to meet environmental needs, in the South. In this interpretation, $\mathbf{r}$ atively little gas is being transported from the major production centers in the South to meet demand in the North. Hence, demand in the North is believed to drive the market for gas exported from the United States (NPC 1992).

However, as will be discussed in Section 2, the flow of gas from the South to the North is substantial and exceeds that to be expected under a North-South policy. The market for gas exported from the United States to meet the demand in all of Mexico can be better understood in terms of the willingness of PEMEX to import gas to meet the requirements of non-PEMEX users.

\subsection{NORTH AMERICAN FREE TRADE AGREEMENT}

This section contains a broad overview of NAFTA and a brief discussion of how it might affect the natural gas trade between the United States and Mexico. In January 1991, the United States, Canada, and Mexico agreed to hold negotiations to create an agreement on free trade. On August 12, 1992, the Canadian Minister of Industry, Science, and Technology; the Mexican Secretary of Trade and Industrial Development; and the U.S. Trade Representative completed negotiations. The agreement has been signed by the three governments and now awaits approval by the U.S. Congress.

If approved, NAFTA would formally establish a free trade area covering Canada, Mexico, and the United States, consistent with the General Agreement on Tariffs and Trade. The general objectives of NAFTA that would be furthered by this free trade area include eliminating barriers to trade, promoting conditions of fair competition, and increasing investment opportunities. NAFTA would generally eliminate import and export restrictions, such as quotas and import licenses; however, special rules apply to energy and basic petrochemicals, as well as to automobiles, textiles, and agricultural products. The reservations and special provisions relating to energy and petrochemicals are contained in Annex 602.3 of the agreement. 
The following are the salient provisions regarding energy and petrochemicals in that annex:

- No country may impose a tax, duty, or charge on the export of energy or basic petrochemicals unless the same tax, duty, or charge is applied to such goods when consumed domestically.

- Goods, activities, and investments in Mexico in the oil, gas, refining, basic petrochemical, nuclear, and electricity sectors are reserved by Mexico to the Mexican State (e.g., transportation and distribution of natural gas up to and including the first sale).

- NAFTA investors are allowed to acquire, establish, and operate facilities in Mexico in nonbasic petrochemical goods and in electrical generating facilities for "own use," cogeneration, and independent power production.

- To promote cross-border trade in natural gas and basic petrochemicals, NAFTA provides that state enterprises, end users, and suppliers have the right to negotiate supply contracts.

- The IPPs, CFE, and electric utilities in other NAFTA countries have the right to negotiate power purchase and sale contracts.

The provision that goods, activities, and investments in Mexico in the oil, gas, refining, and basic petrochemical sectors are reserved to the Mexican State conforms to Article 27 of the Mexican Constitution, which specifically prohibits all foreign investment in oil and gas exploration and development.

It is not clear how the provision intended to promote cross-border trade in natural gas would affect gas imported into Mexico because it would still have to be sold to PEMEX, which would then resell the gas to the end users afier transporting it in PEMEX-owned pipelines.

The NAFTA energy provision most likely to enhance the market for natural gas from the United States is the one that encourages private investment in Mexico in nonbasic petrochemicals and in electrical generation (i.e., cogeneration, independent power production, and generation for "own use"). (This provision has been implemented for investment in electrical generation by the December 1992 amendments to the Public Service Law for Electrical Energy.) The transmission, distribution, and public service sales of electricity from the privately owned generating facilities are reserved to CFE. Natural gas is an environmentally suitable fuel for electrical generation and for producing industrial process heat. To the extent that the energy provisions in NAFTA would cause these industries to locate in Mexico, the provisions would increase the demand for natural gas. If these industries locate in the North, near the border with the United States, then the most convenient source of natural gas would be exports from the United States. The energy provisions would further facilitate exports by allowing these end users to enter into supply 
contracts that would be negotiated directly with U.S. exporters, although PEMEX-owned pipelines would have to be used to transport the gas to the end users under current law and under NAFTA (U.S. International Trade Commission 1993).

The general provisions of NAFTA could have some indirect effect on the market for gas exports to Mexico. These general provisions apply to industries that are end users of electricity, which may be generated in gas-fired plants. The industries that are most likely to use electricity from generating plants fueled by imported gas and are most likely to be affected by NAFTA are the maquiladoras and other industries existing in or to be located in the North. NAFTA provides generally for the progressive elimination of all tariffs on goods qualifying as North American under its rules of origin. Similarly, NAFTA provides for the termination of current "drawback" and similar programs that provide for the refund or waiver of customs duties on materials used in the production of goods subsequently exported to another NAFTA country (NAFTA 1992). The maquiladora program is one such program. Thus, NAFTA would gradually eliminate the export.incentives of the maquiladora program as tariffs are removed in stages. On the other hand, pursuant to the general provisions of NAFTA, Mexico would remove restrictions on domestic sales of the products of maquiladoras. NAFTA might encourage more maquiladora-like plants to be sited in Mexico; however, as the Bush administration pointed out, these plants would no longer have a special incentive to locate near the U.S. border once restrictions on domestic sales were removed (Bush Administration 1991).

Two hypotheses are advanced on whether a NAFTA-induced expansion would occur in the North, where the expansion could be served by exports of gas from the United States, or in the South (Garcia 1993). The hypothesis that the expansion would be in the South is supported by two arguments: (1) that NAFTA, by opening the Mexican market to maquiladoras, reduces the incentive to locate near the border; and (2) that the infrastructure in the North is inadequate, so expansion in the North would require expensive infrastructure improvements whose costs would be passed on to the industrial sector. The counterargument is that the factories in the North are newer and more efficient, so it would make more financial sense to expand the more efficient facilities in the North than to expand less efficient facilities or build new facilities in the South. New industry in the North would most likely increase the demand for natural gas indirectly through the use of electricity generated by gas-fueled plants, rather than through direct use of gas for process heat. 


\section{HISTORICAL PRODUCTION AND CONSUMPTION OF NATURAL GAS IN MEXICO}

This section discusses recent and current production and consumption of natural gas in Mexico. The issues discussed are gas resources, production, consumption by sector, pipeline infrastructure, and natural gas trade with the United States.

\subsection{RESOURCES}

Mexico's current proven natural gas reserves stood at 70.9 trillion cubic feet (TCF) in 1991. For comparison, the proven reserves for the United States and Canada are 169.5 TCF and 96.5 TCF, respectively. The locations of those Mexican gas reserves in production are shown on the map in Figure 2.1. PEMEX divides the locations into three broad administrative regions: the North Region, which runs along the Gulf of Mexico and comprises the basins centered near Reynosa, Tampico, Poza Rica, and Veracruz; the South Region, located onshore farther south on the Gulf of Mexicc along the Isthmus of Tehuantepec; and the Marine Region, located offshore in the Bay of 'ampeche. All reserves except 26.7 TCF in the basin near Tampico (the Chicontepec Basin) have been developed and are now in production. The current reserves are 36.6 TCF in the North Region, 23.2 TCF in the South Region, and 11.1 TCF in the Marine Region. Natural gas in the South and Marine regions is associated with oil; in the North Region, gas is generally nonassociated. In addition, unproven reserves are estimated at 180 TCF (NPC 1992).

Table 2.1 shows reserves and production for the last 10 years. The table shows a steady decline in reserves, approximately $10 \%$ overall, from $77.0 \mathrm{TCF}$ to $70.0 \mathrm{TCF}$. The decline in reserves shows that exploration and development have not kept pace with production.

Exploration and production are proceeding in the South and Marine regions. Because natural gas in these regions is associated with oil, much of the cost of exploration and production can be allocated to oil, rather than to natural gas. The cost allocated to exploration and production is $\$ 1.14 /$ thousand cubic feet (MCF) for nonassociated gas and $\$ 0.25 / \mathrm{MCF}$ for associated gas (Lajous 1992).

\subsection{PRODUCTION}

Natural gas production peaked in 1982 at 1,548 BCF ( 4,240 million cubic feet per day [MMCF/d]) and, as shown in Table 2.1, declined steadily, reaching 1,312 BCF annually $(3,620 \mathrm{MMCF} / \mathrm{d})$ by 1992 . Gas production by region for the last three years is given in Table 2.2. This table shows slight decreases in production in the North and South regions and slight increases in the Marine Region. 


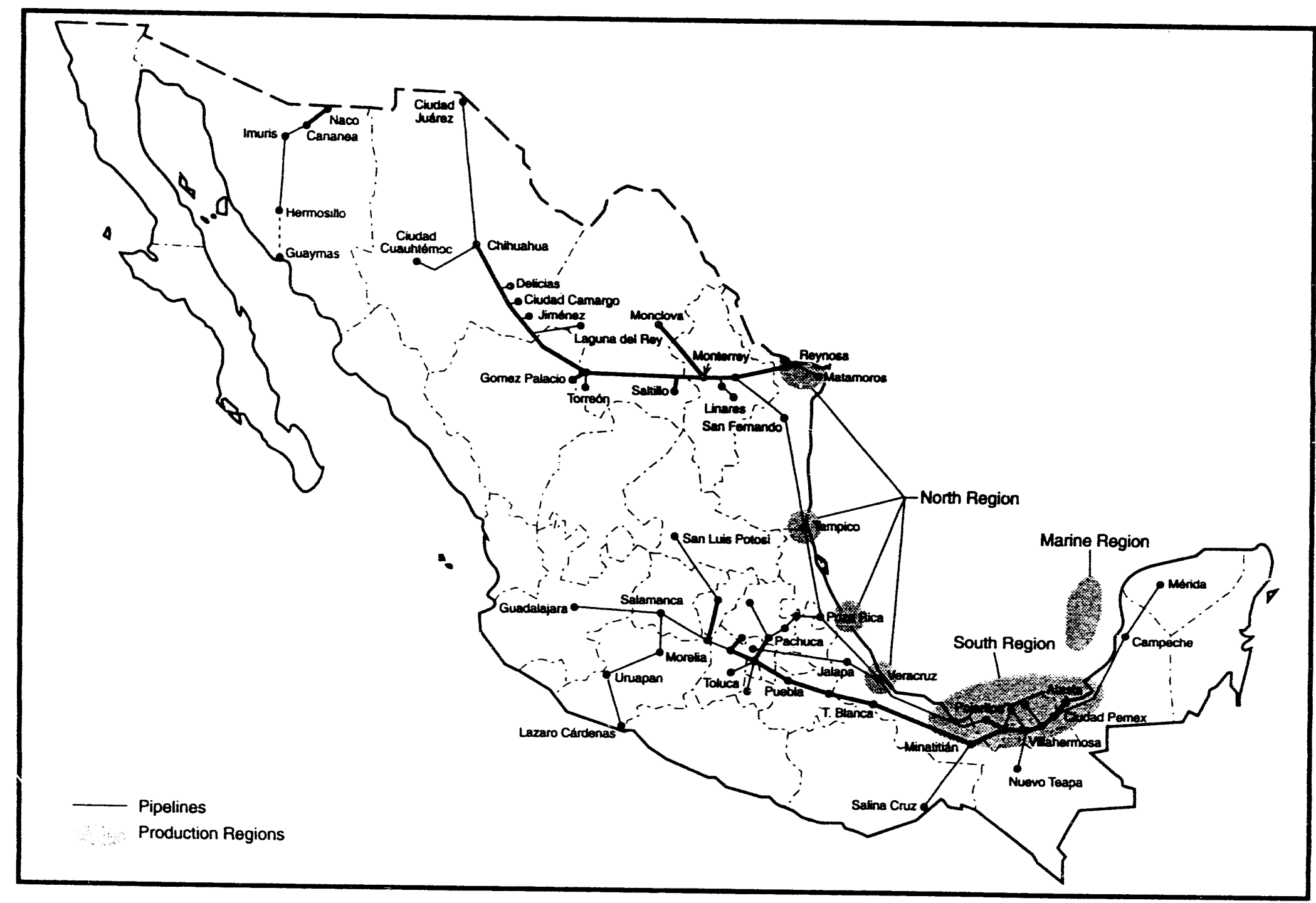

FIGURE 2.1 Natural Gas in Mexico: Production Regions and Pipelines (Source: Adapted from PEMEX 1992a,
p. 278) 
TABLE 2.1 Mexican Reserves and Production of Natural Gas, 1983-1992

\begin{tabular}{cccc}
\hline Year & $\begin{array}{c}\text { Reserves } \\
\text { (TCF) }\end{array}$ & $\begin{array}{c}\text { Annual Production } \\
\text { (BCF) }\end{array}$ & $\begin{array}{c}\text { Ratio of Reserves } \\
\text { to Production }\end{array}$ \\
\hline & & 1,479 & 52.0 \\
1983 & 77.0 & 1,370 & 56.0 \\
1984 & 76.7 & 1,315 & 58.2 \\
1985 & 76.5 & 1,252 & 60.5 \\
1986 & 75.8 & 1,277 & 58.5 \\
1987 & 74.9 & 1,269 & 57.8 \\
1988 & 73.4 & 1,304 & 55.8 \\
1989 & 72.7 & 1,333 & 53.7 \\
1990 & 71.5 & 1,326 & 53.5 \\
1991 & 70.9 & 1,312 & 53.4 \\
1992 & 70.0 & & \\
\hline
\end{tabular}

Source: PEMEX (1992a).

TABLE 2.2 Production of Natural Gas by Region, 1990-1992

\begin{tabular}{lccc}
\hline & \multicolumn{3}{c}{ Gas Production $(\mathrm{MMCF} / \mathrm{d})^{\mathrm{a}}$} \\
\cline { 2 - 4 } Region & 1990 & 1991 & 1992 \\
\hline North & 475 & 473 & 464 \\
South & 2,059 & 2,000 & 1,946 \\
Marine & 1,118 & 1,160 & 1,174 \\
Total & 3,652 & 3,633 & 3,584 \\
\hline
\end{tabular}

a Production per day is average production per day (i.e., annual production divided by $365)$, unless otherwise noted.

Sources: PEMEX (1990, 1991b, 1992b). 
Because most of the natural gas being produced (approximately $83 \%$ ) is associated with crude oil, the gas contains relatively high proportions of hydrogen sulfide, carbon dioxide, and higher hydrocarbons (e.g., ethane, propane, and butane) that are removed before the gas is used. PEMEX operates $\mathbf{1 5}$ gas processing plants that remove these constituents. Five are sweetener plants that remove hydrogen sulfide. Seven are cryogenic plants, and three are absorption plants that extract the propanes and butanes as LPG, which is widely used in the residential/commercial sector and in PEMEX basic petrochemical plants as feed, and potentially could be widely used in the transportation sector. Ethane is also separated for use in PEMEX petrochemical plants. Of the 15 gas processing plants, only one is located in the North, at Reynosa (PEMEX 1992a).

Figure 2.2 gives the disposition of the production for 1992. Of the total production of 3,584 MMCF/d, $107 \mathrm{MMCF} / \mathrm{d}$ was flared or lost as carbon dioxide, $127 \mathrm{MMCF} / \mathrm{d}$ was taken off in sulfur removal, and $540 \mathrm{MMCF} / \mathrm{d}$ was taken off in extracted or liquefied hydrocarbons. Of the resulting sweet $5 n$, PEMEX used $287 \mathrm{MMCF} / \mathrm{d}$ in its facilities, including some for repressurizing of oil welis. The remainder $(2,525 \mathrm{MMCF} / \mathrm{d})$ was delivered to the pipeline. An additional $285 \mathrm{MMCF} / \mathrm{d}$ :vas condensed in the pipeline during transport and added to the supply of LPG. Only about two-thirds of the production (2,237 MMCF/d) was available for delivery from pipelines as dry gas to PEMEX petrochemical facilities and to other users (PEMEX 1992b).

\subsection{CONSUMPTION BY SECTOR}

Consumption of natural gas in Mexico can be divided into five sectors: (1) PEMEX production of petrochemicals, (2) industrial (non-PEMEX) use, (3) electrical generation, (4) residential and commercial use, and (5) transportation. Table 2.3 gives consumption by sector for the years, 1986-1992 (data primarily from PEMEX). Historically, no consumption has occurred in the transportation sector.

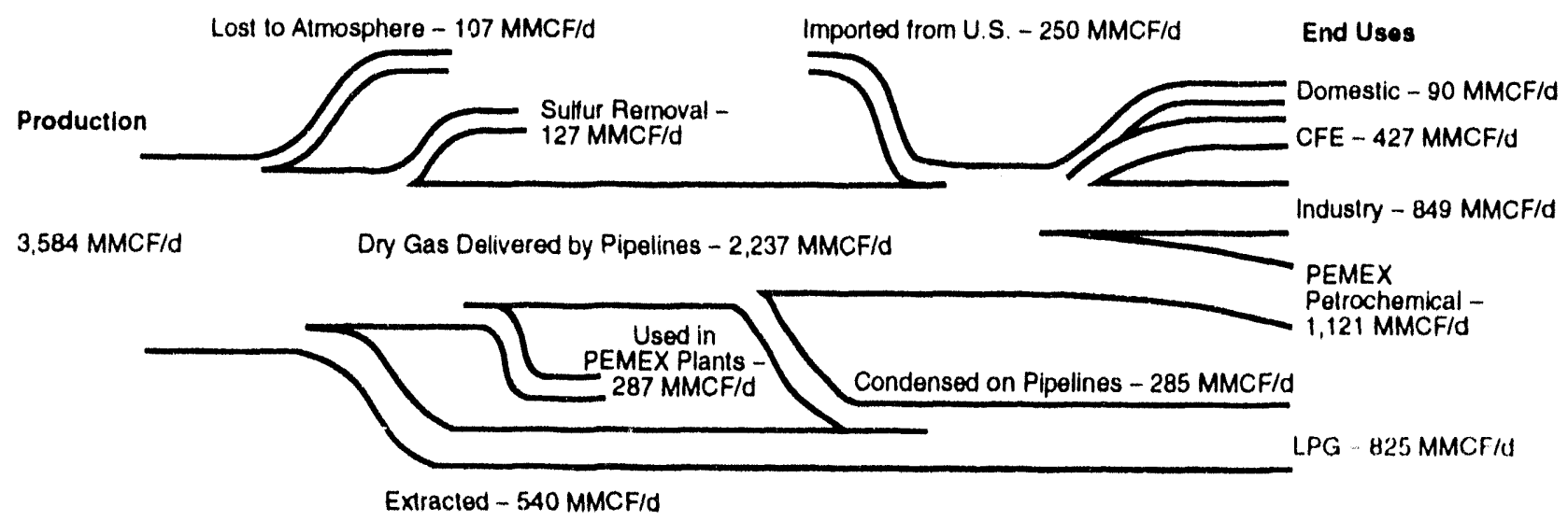

FIGURE 2.2 Production and Consumption of Natural Gas in Mexico, 1992 (Source: PEMEX 1992a, p. 164; source indicates a measurement error between gas produced and gas delivered of $1 \mathrm{MMCF} / \mathrm{d}$ ) 
TABLE 2.3 Gas Consumption by Sector, 1986-1992

\begin{tabular}{|c|c|c|c|c|c|c|c|}
\hline \multirow[b]{2}{*}{ Sector } & \multicolumn{7}{|c|}{ Gas Consumption (MMCF/d) } \\
\hline & $1986^{\mathrm{a}}$ & $1987^{\mathrm{a}}$ & $1988^{a}$ & $1989^{\mathrm{a}}$ & $1990^{\mathrm{a}}$ & 1991 & 1992 \\
\hline PEMEX petrochemicals & 1,044 & 1,084 & 1,131 & 1,136 & 1,101 & $1,092^{b}$ & $1,121^{c}$ \\
\hline Industrial & 802 & 767 & 772 & 775 & 792 & $828^{d}$ & $849^{d}$ \\
\hline Electrical & 285 & 301 & 288 & 288 & 364 & $441^{e}$ & $427^{e}$ \\
\hline Residential/commercial & 85 & 87 & 90 & 93 & 90 & $90^{f}$ & $90^{f}$ \\
\hline Totalg & 2,219 & 2,271 & 2,282 & 2,290 & 2,334 & $2,451^{b}$ & $2,487^{\mathrm{c}}$ \\
\hline \multicolumn{8}{|c|}{ a Source: PEMEX (1991a). } \\
\hline \multicolumn{8}{|c|}{ b Source: PEMEX (1991b). } \\
\hline \multicolumn{8}{|c|}{ c Source: PEMEX (1992b). } \\
\hline \multicolumn{8}{|c|}{$\begin{array}{l}\text { By difference calculated by using values given in Memoria de Labores (PEMEX 1991b, } \\
\text { 1992b) for deliveries to users. }\end{array}$} \\
\hline \multicolumn{8}{|c|}{ e Computed from CFE (1992). } \\
\hline \multicolumn{8}{|c|}{ f Assumed to be unchanged from the previous year. } \\
\hline
\end{tabular}

The total consumption, all of which is supplied by PEMEX, equals the natural gas delivered to the pipeline from domestic production plus the gas imported from the United States. Because natural gas is such a desirable fuel, demand for it exceeds the amount that can be supplied (i.e., consumption is not equivalent to demand). In the electrical sector, at least, the supply of gas to CFE in recent years has been too small to run certain gas-fired generating units at optimal load factors (Blanco and Cristerna 1993).

\subsubsection{PEMEX Petrochemicals}

The PEMEX petrochemical plants have been the largest users of natural gas in Mexico. Over the past seven years (Table 2.3), their consumption of dry gas has fluctuated within a narrow range near 1,100 MMCF/d. In 1992, a year typical of recent production, PEMEX operated petrochemical plants at 19 sites. These petrochemical plants consumed $1,121 \mathrm{MMCF} / \mathrm{d}$ (in addition to a fraction of the $540 \mathrm{MMCF} / \mathrm{d}$ extracted as LPG) to produce 48 chemicals totaling 19 million tons. The 10 chemicals with the largest tonnage (over 350,000 tons) were feedstock for carbon black, dry ice, ammonia, ethane, ethylene, pentane, sulfur, oxygen, toluene, mixed xylenes, and dichloroethane (PEMEX 1992b). 
At nine of the sites, both basic and secondary petrochemicals are produced; at one site, only basic petrochemicals are produced; and at another site, cnly secondary petrochemicals are produced. At the remaining sites, only unrestricted petrochemicals are produced (unrestricted petrochemicals are also produced by private industry) (PEMEX 1992b).

As part of its reorganization, PEMEX is reviewing the profitability of its petrochemical enterprises. Production of ammonia is one of the first operations to be affected. About 25\% of Mexico's ammonia production was exported in 1992, and as a result of a decline in world prices for ammonia, PEMEX no longer considers such exports to be profitable. In 1992, one of the oldest ammonia production facilities, a 30,000-ton/yr facility at Consoleacaque, was closed. In the first quarter of 1993 , a 300,000 -ton/yr facility there was also closed. In addition, several other ammonia facilities were shut down temporarily. These actions currently make an additional amount of gas of about $100 \mathrm{MMCF} / \mathrm{d}$ available for sale to non-PEMEX users (Flores 1993).

A number of private petrochemical companies buy basic feedstocks from PEMEX to produce chemical intermediates and final products such as fertilizers, synthetic resins, chemical fiber, and elastomers. The principal companies are the Alfa, Cydesa, Idesa, Celanese, Resistol, and Novum groups, many of which are subsidiaries of foreign corporations. These companies also purchase natural gas for process heat from PEMEX; their consumption is included in the chemical category of industrial users (Flores 1993).

\subsubsection{Industrial Sector (Excluding PEMEX)}

Historically, the industrial sector (excluding PEMEX) has been the second largest user of natural gas, accounting for more than one-third of the gas delivered via the pipeline system (Table 2.3); however, gas use by the industrial sector has increased significantly, by about $10 \%$, during the past two years. Much of this increase is occurring in the North of Mexico, and this increased demand is largely being met by imports from the United States. Figure 2.3 gives natural gas usage for six major industries: metal production; chemicals; cellulose and paper; mining; glass; and food. The gas consumed in cogeneration is included in the consumption figures for the industrial owners of the cogeneration facility.

\subsubsection{Electrical Sector}

\subsubsection{Federal Electricity Commission (CFE)}

Although CFE began operation of energy-efficient, gas-fired combined-cycle plants with two units in 1975, CFE did not use natural gas in a major way until the early 1980s, when Mexico shifted its strategy from exporting gas not used by PEMEX to making that gas available for domestic uses. The CFE now operates seven gas-fired combined-cycle units at 


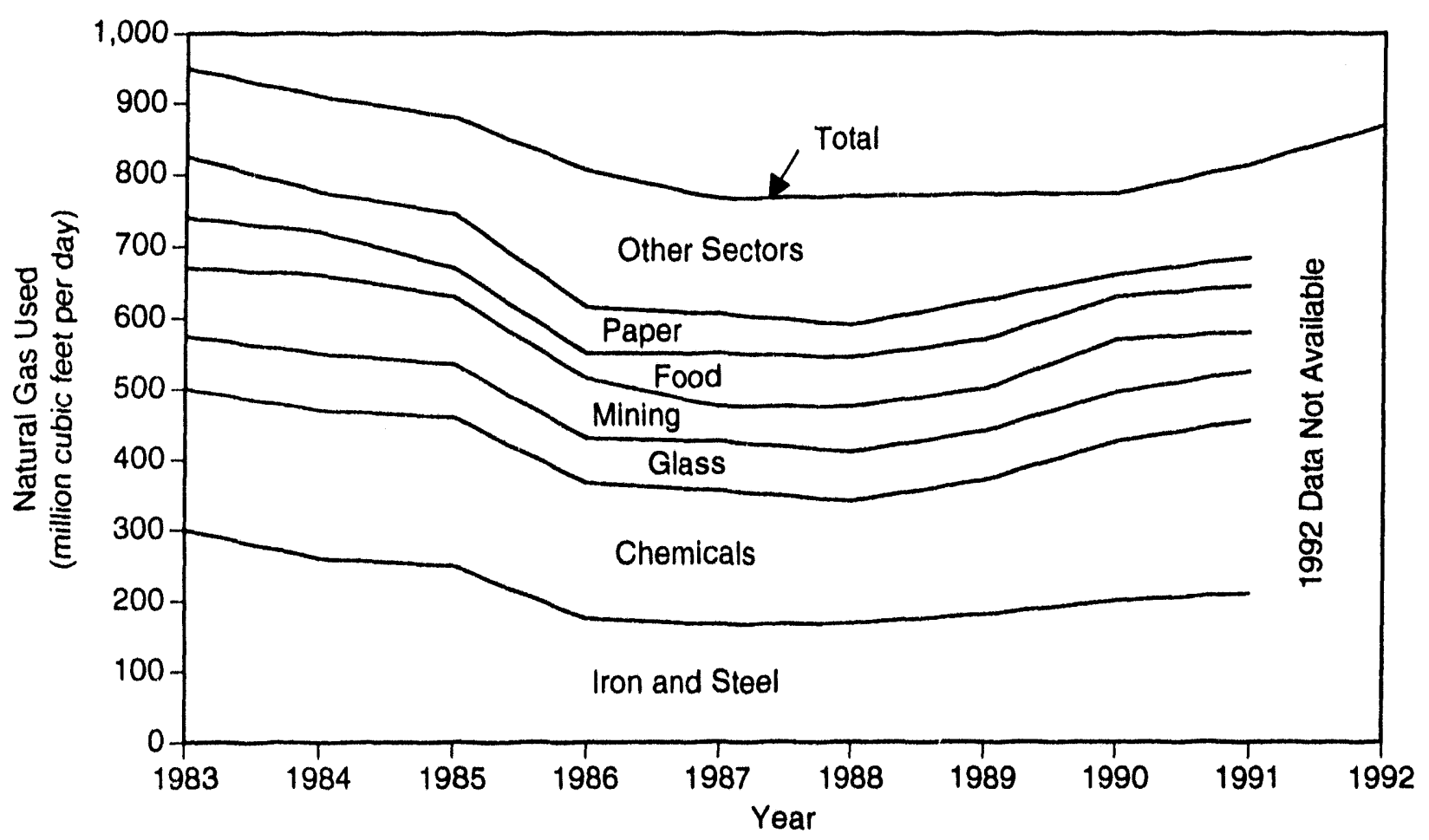

FIGURE 2.3 Natural Gas Used by Mexican Industry Other than PEMEX (Sources: Bazan 1993, data for 1983-1991; PEMEX 1992a, data for 1992)

five locations (Huinala, Gómez Palacio, Tula, Dos Bocas, and El Sauz). The CFE also repowered oil-fired steam stations to natural gas in the Valley of Mexico in 1990 and in the North in 1991 to improve air quality in urban centers.

During the period of 1985-1992, when CFE's total generation increased from 85.2 million terawatt-hours (TWh) to $121.6 \mathrm{TWh}$, the fraction of electrical energy generated from natural gas rose from $8.6 \%$ to $11.9 \%$ (Figure 2.4). The figure also shows natural gas usage by CFE by type of unit (steam plants, combined cycle, or gas turbine) for the period of 1985-1992. As can be seen in the figure, the increase in natural gas usage by CFE a few years ago is attributable to the repowering of the steam plants. Although the data show an overall increase in the use of gas by CFE for the period, a decrease in use occurred in 1992 over 1991, even though the overall generation increased by $2.6 \%$. Gas supplies to generating stations in the North were limited in 1992 and continue to be limited in 1993 (Blanco and Cristerna 1993).

The program of conversion of oil-fired generating stations to natural gas created a demand for natural gas that contributed significantly to the increase of exports to Mexico from the United States over the low level that had existed during the 1980s. 
1985 Fuel Share

85.2 TWh Gross Generation
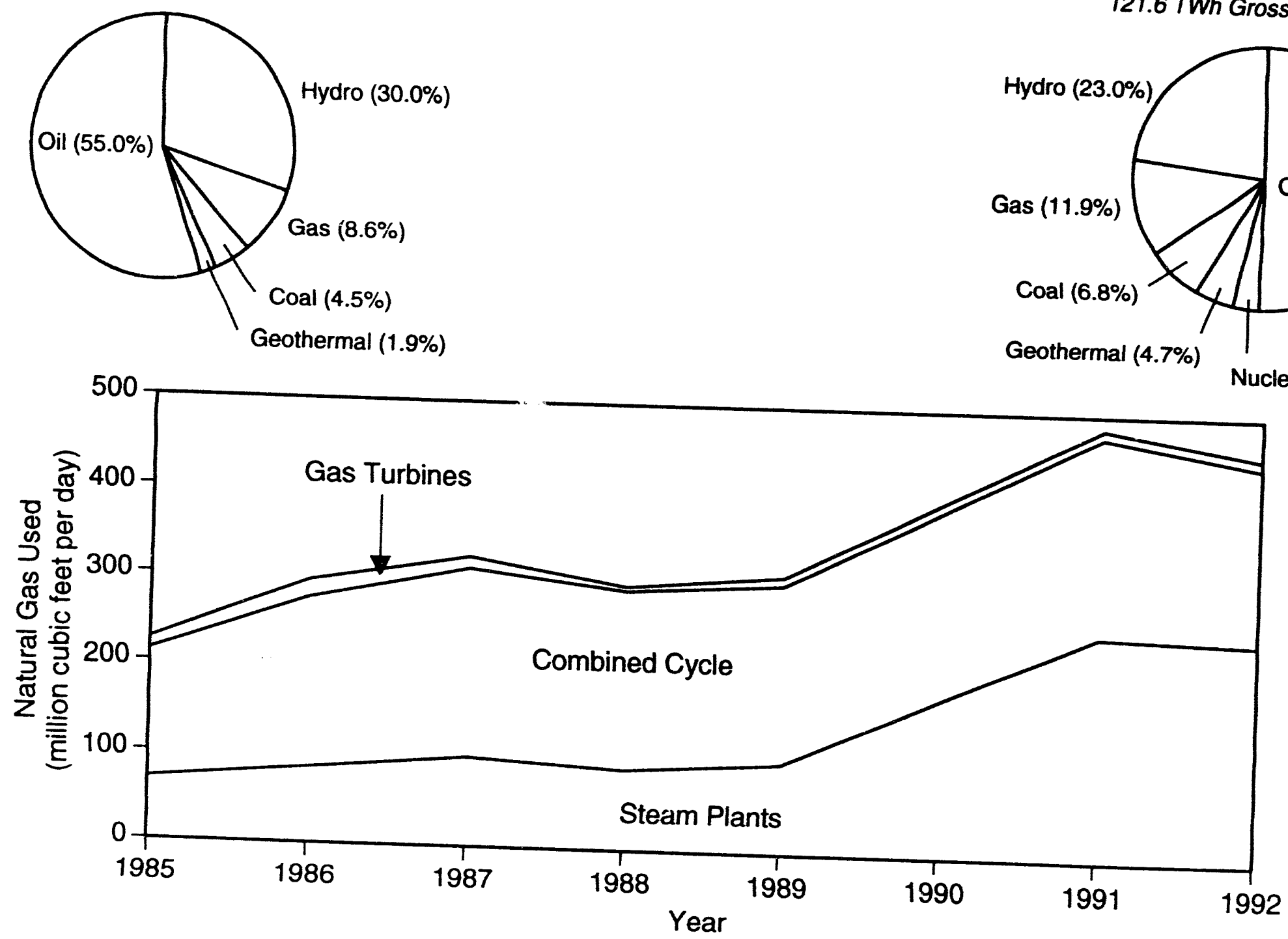

1992 Fuel Share

121.6 TWh Gross Generation

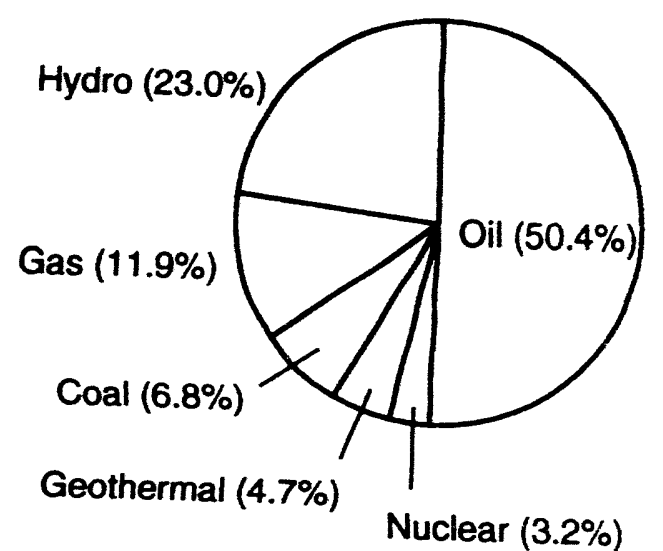

FIGURE 2.4 Natural Gas Used in Electrical Generation in Mexico (Sources: CFE 1986-1992) 


\subsubsection{Self-Generation and Independent Power Production}

An estimated 3,000 MWe is being produced by cogeneration, chiefly in the oil, petrochemical, steel, sugar, chemical, and paper industries (DOC 1992); however, until the recent changes in Mexico's Public Service Law for Electrical Energy, privately owned electrical generation facilities and cogeneration facilities were not permitted to sell electricity to CFE. Now, CFE is planning to purchase electricity from two major gas-fired, privately owned IPP facilities. These IPPs would be located in Mérida in Yucatan and Rosarito in Baja California. These projects and their projected consumption of natural gas are discussed in Section 3.3.3.2.

\subsubsection{Residential/Commercial Sector}

Natural gas is used in the residential/commercial sector (referred to by PEMEX as the "domestic" sector) for hot water heating and for cooking. Approximately $90 \mathrm{MMCF} / \mathrm{d}$ is used in this sector (PEMEX 1991a). Gas for this sector is provided by local gas distribution companies that buy the gas at wholesale prices from PEMEX, transport the gas in pipelines that they own, and sell the gas at retail rates. These companies are analogous to gas distribution utilities in the United States. These companies are required to obtain permits from SECOFI and permits from municipalities to lay pipelines under public rights-of-way.

Eleven gas distribution companies serve an estimated 600,000 customers, and five new companies are either being organized or have been organized but are not yet operating (Vazquez 1993). The smaller companies serve predominantly residential and commercial customers, while the larger companies serve large industrial customers as well. Table 2.4 contains information about these gas distribution companies.

\subsubsection{Transportation Sector}

Although, historically, no consumption of natural gas has occurred in the transportation sector, conversion of vehicles to natural gas is seen as a way to improve air quality in a congested metropolis such as Mexico City or Monterrey. The government of Mexico City, the Federal District Department (DDF), has an ambitious program for converting vehicles to LPG or CNG in metropolitan Mexico City (DDF 1992). The vehicles subject to conversion include licensed public service taxis, minibuses, buses, cargo trucks, garbage trucks, and other vehicles owned by the DDF.

In all, the program calls for the conversion of nearly 330,000 vehicles. The Mexico City program is now in the pilot stage and is being supported by the Mexican Petroleum Institute (IMP), which does petroleum and gas research as an affiliate of SEMIP and PEMEX. Approximately 50 vehicles have been converted to date, and one fueling station has been established. In Monterrey, the Monterrey Institute of Technology and Higher Education (ITESM) operates one vehicle fueled by liquefied natural gas in a research program; however, no municipal program exists in Monterrey as yet. 
TABLE 2.4 Local Gas Distribution Companies

\begin{tabular}{|c|c|}
\hline Location & Description \\
\hline Apodaca & Company organized but not yet operating. \\
\hline Cananea & Gas supply imported at Naco; 2.9 MMCF used in 1990. \\
\hline Cerralvo & Company organized but not yet operating. \\
\hline Chihuahua & New company under discussion. \\
\hline Ciudad Juárez & $\begin{array}{l}\text { Two operating companies: Distributor of Natural Gas of } \\
\text { Juárez used 5.4 MMCF in 1990; Juárez Gas Co. used } \\
1.1 \text { MMCF in 1990. The new Samalayuca pipeline } \\
\text { could increase use. }\end{array}$ \\
\hline Guadalajara & New company under discussion. \\
\hline Laredo & 1.8 MMCF used in 1990. \\
\hline Matamoros & 0.1 MMJF used in 1990. \\
\hline Mexico City & Small PEMEX subsidiary. \\
\hline Monterrey & $\begin{array}{l}\text { Three distribution companies, at least one of which } \\
\text { serves industrial customers. In 1990, Gas Industrial of } \\
\text { Monterrey, S.A., used } 30 \text { MMCF; Compania Mexicana } \\
\text { de Gaz, S.A. (Mexican Gas Co.) used 17.0 MMCF; and } \\
\text { a CFE-owned distributor used 11.7 MMCF. }\end{array}$ \\
\hline Querétaro & Small PEMEX subsidiary. \\
\hline Saltillo & 0.7 MMCF used in 1990. \\
\hline Santa Catarina & Company organized but not yet operating. \\
\hline
\end{tabular}

Source: Vazquez (1993).

Although considerable interest exists in the private sector among manufacturers of conversion products, investing in CNG vehicles is restricted by serious impediments. First, the Secretary of the Treasury and Finance is considering a tax that would reduce or eliminate the price advantage at the fueling station between natural gas and petroleum fuels. Because a capital investment in conversion equipment is required, a fuel price differential is necessary for CNG vehicles to make economic sense. Second, the environmental agency, SEDESOL, has not yet issued emission standards. Third, the nature of the conditions that will be included in business permits issued by SECOFI is not yet known. Fourth, very little infrastructure (e.g., fueling stations) exists now (Vazquez 1993). 


\subsection{MEXICO'S PIPELINE INFRASTRUCTURE}

The Mexican natural gas pipeline network and the U.S. export points are shown on the map in Figure 2.1. Essentially two pipeline systems exist in Mexico, a northern system running from Reynosa to Ciudad Juárez and a southern system running from the Yucatan and the Gulf through Mexico City to Guadalajara. The two systems are connected by a pipeline known as the National Trunkline, which branches from the northern system at Las Ramonas and may currently be moving as much as $400 \mathrm{MMCF} / \mathrm{d}$ at times from the southern pipeline system (Barcenas 1993).

The southern system transports gas from major production centers along the Gulf of Mexico to a wide variety of users in the South. The main pipeline system in the North of Mexico is a dual system running from the Reynosa area to Monterrey and on to Chihuahua (Figure 2.5). Many major distributing lines branch from this system, which currently moves about $250 \mathrm{MMCF} / \mathrm{d}$ from fields around Reynosa to serve PEMEX, CFE, and indusurial users in the North. The system is also connected to the U.S. export points at Hidalgo and Penitas, Texàs.

A single pipeline to Chihuahua connects Ciudad Juárez with the northern system. This pipeline serves the CFE plant at Samalayuca and is connected to the U.S. export point at El Paso, Texas. In addition, a smaller line from Naco, Arizona, to Hermosillo is not connected with the main northern system; the line serves industries in the state of Sonora with gas exported from the United States (Figure 2.5). Table 2.5 lists the size and current use of major pipelines in the North of Mexico that are involved in importing gas from the United States.

\subsection{TRADE IN NATURAL GAS BETWEEN THE UNITED STATES AND MEXICO}

The United States and Mexico have traded in natural gas since shortly after the Second World War. Since 1949, the United States has exported small volumes of gas to serve cross-boundary markets that are isolated from the indigenous supply. In the early days of the trade, exports to these Mexican markets were in the range of 10-15 BCF/yr (NPC 1992); however, this export trade declined in the 1970s and 1980s and was reduced to an average export of approximately $2 \mathrm{BCF} / \mathrm{yr}$ by the mid-1980s.

During some periods since 1952, the United States has imported gas from Mexico (NPC 1992). Between 1957 and 1971, imports averaged $40 \mathrm{BCF} / \mathrm{yr}$; however, very little gas was imported between 1972 and 1979. Significant imports were resumed in 1980 with the signing of an agreement between PEMEX and Border Gas, a consortium of six U.S. gas transmissicn companies. F om 1980 through 1984, imports to the United States averaged approximately $86 \mathrm{BCF} / \mathrm{yr}$. The agreement called for maximum deliveries of $300 \mathrm{MMCF} / \mathrm{d}$ and quarterly adjustments in accordance with a composite index of world crude oil prices. The initial price was $\$ 3.625 / \mathrm{MCF}$; however, over time, PEMEX requested a price increase to 


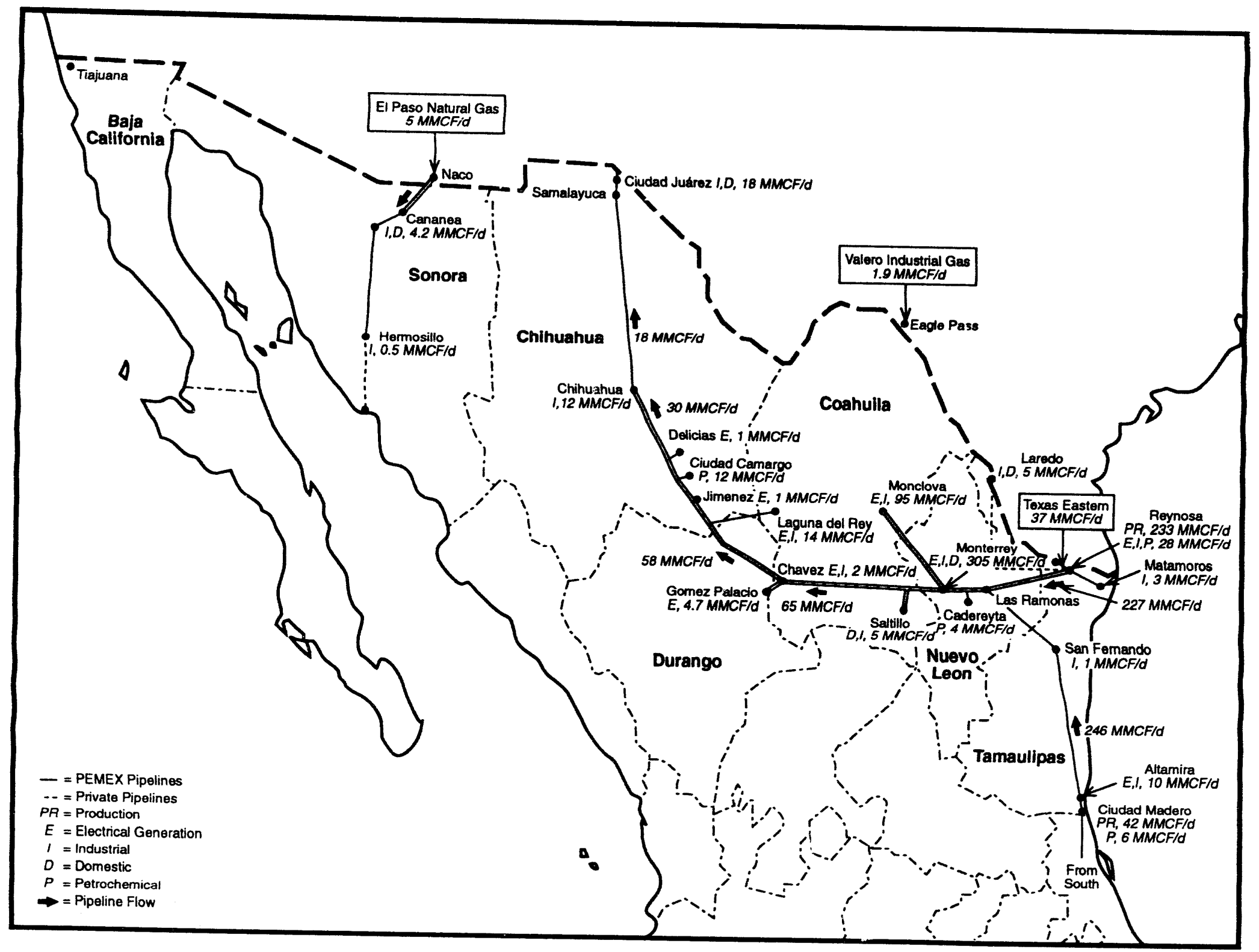

FIGURE 2.5 Mexican Gas Industry in 1990: Pipelines and Major Consumption Points in the North (Sources: Map adapied from PEMEX 1992a; consumption data from Bazan 1993) 
TABLE 2.5 Size and Use of Major Pipelines in Northern Mexico, 1990

\begin{tabular}{|c|c|c|c|c|}
\hline $\begin{array}{c}\text { Location } \\
\text { (Figure 2.5) }\end{array}$ & $\begin{array}{c}\text { Length } \\
\text { (mi) }\end{array}$ & $\begin{array}{l}\text { Diameter } \\
\text { (in.) }\end{array}$ & $\begin{array}{c}\text { Flow } \\
(\mathrm{MMCF} / \mathrm{d})^{\mathrm{a}}\end{array}$ & Direction \\
\hline $\begin{array}{l}\text { Providencia - } \\
\text { Border }^{\mathrm{b}}\end{array}$ & 13 & 42 & 36 & South \\
\hline $\begin{array}{l}\text { Reynosa - } \\
\text { Providencia }^{c}\end{array}$ & 8 & 24 & 191 & West \\
\hline $\begin{array}{l}\text { Providencia - } \\
\text { Las Ramonas }\end{array}$ & 81 & 36,24 & 227 & West \\
\hline $\begin{array}{l}\text { Cactus - } \\
\text { San Fernando }\end{array}$ & 691 & 48 & $221-246^{d}$ & North \\
\hline $\begin{array}{l}\text { San Fernando - } \\
\text { Las Ramonas }\end{array}$ & 91 & 42 & 245 & North \\
\hline $\begin{array}{l}\text { Las Ramonas - } \\
\text { Monterrey }\end{array}$ & 46 & 36,24 & 473 & West \\
\hline $\begin{array}{l}\text { Monterrey - } \\
\text { Chavez }\end{array}$ & 174 & 16,24 & 65 & West \\
\hline $\begin{array}{l}\text { Chavez - } \\
\text { Chihuahua }\end{array}$ & 271 & 12,24 & $58-30^{\circ}$ & $\begin{array}{l}\text { North- } \\
\text { west }\end{array}$ \\
\hline $\begin{array}{l}\text { Chihuahua - } \\
\text { Ciudad Juárez }\end{array}$ & 213 & 16 & 18 & North \\
\hline $\begin{array}{l}\text { Naco, Ariz. - } \\
\text { Hermosillo }\end{array}$ & 212 & 16 & 4.7 & South \\
\hline
\end{tabular}

a Calculated from data of Bazan (1993) and from U.S. export data (ANL 1992).

b Providencia is an interconnection $8 \mathrm{mi}$ west of Reynosa.

c A pipeline between Reynosa and Laredo not listed in PEMEX (1992a) delivered about $5 \mathrm{MMCF} / \mathrm{d}$ to Laredo.

d Gas (26 MMCF/d) enters the system at Ciudad Madero-Altamira.

- Gas delivered at branch points along the line.

Source (unless otherwise noted): PEMEX (1992a). 
\$4.94/MCF to achieve parity with gas imports from Canada, and Border Gas reduced its purchases (White 1992). In May 1983, the price was set at $\$ 4.40 / \mathrm{MCF}$ pursuant to an agreement between the organizations.

In November 1984, PEMEX and Border Gas decided mutually to suspend imports to the United States indefinitely. From the U.S. perspective, imports from Mexico became less attractive because of declining wellhead prices and because domestic production capacity well exceeded demand (White 1992). From the Mexican perspective, the gas that would have been exported has greater value when used domestically to displace use of high-sulfur fuel. Natural gas imports from and exports to Mexico from 1977 through 1992 are shown in Table 2.6.

Five border crossings are currently in use: Hidalgo, Penitas, Eagle Pass, and El Paso, all in Texas; and Naco, Arizona. Together, they have an annual export capacity of about $900 \mathrm{MMCF} / \mathrm{d}$. The crossings at Hidalgo and Penitas are the largest and account for

TABLE 2.6 Natural Gas Trade between the United States and Mexico, 1977-1992

\begin{tabular}{|c|c|c|c|c|}
\hline \multirow[b]{2}{*}{ Year } & \multicolumn{2}{|c|}{ U.S. Imports } & \multicolumn{2}{|c|}{ U.S. Exports } \\
\hline & $\begin{array}{l}\text { Volume } \\
\text { (BCF) }\end{array}$ & $\begin{array}{c}\text { Price } \\
(\$ / \mathrm{MCF})\end{array}$ & $\begin{array}{c}\text { Volume } \\
\text { (BCF) }\end{array}$ & $\begin{array}{c}\text { Price } \\
(\$ / \text { MCF })\end{array}$ \\
\hline 1977 & 2.4 & 2.25 & 3.9 & 1.41 \\
\hline 1978 & 0 & - & 4.0 & 1.65 \\
\hline 1979 & 0 & - & 4.3 & 1.97 \\
\hline 1980 & 102.4 & 4.41 & 3.9 & 2.47 \\
\hline 1981 & 105 & 5.01 & 3.3 & 3.37 \\
\hline 1982 & 94.8 & 5.02 & 1.7 & 5.17 \\
\hline 1983 & 75.4 & 4.70 & 1.6 & 4.79 \\
\hline 1984 & 51.5 & 4.49 & 1.9 & 4.48 \\
\hline 1985 & 0 & - & 2.2 & 3.99 \\
\hline 1986 & 0 & - & 1.9 & 3.49 \\
\hline 1987 & 0 & - & 2.1 & 3.18 \\
\hline 1988 & 0 & - & 2.3 & 3.21 \\
\hline 1989 & 0 & - & 17.0 & 2.14 \\
\hline 1990 & 0 & - & 15.7 & 1.88 \\
\hline 1991 & 0 & - & 60.4 & 1.76 \\
\hline 1992 & 0 & - & 95.1 & 1.77 \\
\hline $1993^{a}$ & 0 & - & 13.1 & 1.91 \\
\hline
\end{tabular}

a First quarter only (Source: DOE 1993).

Source: DOE (1992, pp. 20, 24). 
$85 \%$ of the current exports from the United States. Data on these pipeline crossings are given in Table 2.7. The United States has been continuing to export gas to Mexico at Eagle Pass, Texas, and at Naco, Arizona. These exports together have remained steady at about $7 \mathrm{BCF} / \mathrm{yr}$. Little increase in these small exports from these two export points is expected.

In 1989, PEMEX was unable to meet the increased demand for gas from its domestic production when CFE began converting its generating plants from heavy fuel oil to natural gas and industrial use increased. About $40 \mathrm{MMCF} / \mathrm{d}$ was exported from the United States through the transborder connection at Hidalgo. The exports at this gateway increased to about $150 \mathrm{MMCF} / \mathrm{d}$ in 1992, when a second transborder connection to the pipeline system at Penitas (McAllen, Texas) went into operation; however, in the last quarter of 1992, the exports at the combined gateway declined, and only an average of about $95 \mathrm{MMCF} / \mathrm{d}$ was exported during the first half of 1993.

TABLE 2.7 Exports of Natural Gas from the United States to Mexico

\begin{tabular}{|c|c|c|c|c|c|c|c|}
\hline \multirow{2}{*}{$\begin{array}{c}\text { Company } \\
\text { (export point) }\end{array}$} & \multicolumn{7}{|c|}{ Natural Gas (MMCF/d) } \\
\hline & Capacity & $1988^{a}$ & $1989^{a}$ & $1990^{\mathrm{a}}$ & $1991^{b}$ & $1992^{b}$ & $1993^{c}$ \\
\hline $\begin{array}{l}\text { Valero Industrial } \\
\text { (Penitas, Texas) }\end{array}$ & 400 & 0 & 0 & 0 & 0 & $61^{d}$ & 50.4 \\
\hline $\begin{array}{l}\text { Texas Eastern } \\
\text { (Hidalgo, Texas) }\end{array}$ & 370 & 0 & 41 & 36 & 156 & 146 & 44.2 \\
\hline $\begin{array}{l}\text { Valero Industrial } \\
\text { (Eagle Pass, Texas) }\end{array}$ & 6 & 1 & 1 & 2 & 2 & 2 & 1.9 \\
\hline $\begin{array}{l}\text { Western Gas } \\
\text { Interstate (El Paso, } \\
\text { Texas) }\end{array}$ & 111.6 & 0 & 0 & 0 & 4 & 45 & 29.5 \\
\hline $\begin{array}{l}\text { El Paso Natural } \\
\text { Gas (Naco, } \\
\text { Arizona) }\end{array}$ & 14.3 & 5 & 4 & 7 & 3 & 6 & 4.3 \\
\hline Total & 901.9 & 6 & 46 & 45 & 165 & $260^{\mathrm{e}}$ & 130.3 \\
\hline
\end{tabular}

a Data summarized from U.S. export data appearing in database of ANL (1992) on U.S. Federal Energy Regulatory Commission [FERC] Form 14.

b Data summarized from DOE (1991-1993).

c First half of year only.

d Pipeline in operation September to December only.

e Note that PEMEX (1992a, p. 164), gives a value of $250 \mathrm{MMCF} / \mathrm{d}$ for total imports from the United States. 
In 1991, exports began through a reopened transborder connection at El Paso, Texas, primarily to serve the conversion of the CFE generating station at Samalayuca near Ciudad Juárez. These exports rose to $45 \mathrm{MMCF} / \mathrm{d}$ for 1992 , reflecting the completion of conversion at Samalayuca and an increase in the use of gas in the industrial and residential/commercial sectors in the Ciudad Juárez area. Exports at El Paso are also declining, however, averaging about 29.5 MMCF/d during the first half of 1993. These data are also summarized in Table 2.7.

Applications for permit approval of the following five proposed pipeline border crossings are now under consideration at the U.S. Federal Energy Regulatory Commission (FERC): (1) a 600-MMCF/d pipeline at Hidalgo, Texas; (2) a new 300-MMCF/d pipeline at El Paso, Texas; (3) a small pipeline at Sunland Park, New Mexico, with a capacity of 25-50 MMCF/d; (4) a 350-MMCF/d pipeline at Yuma, New Mexico; and (5) a pipeline with a potential capacity of $475 \mathrm{MMCF} / \mathrm{d}$ at San Isidro, California. These crossings are discussed more fully in Section 3. 


\section{FUTURE PRODUCTION AND CONSUMPTION OF NATURAL GAS IN MEXICO}

This section contains projections of the production and consumption of natural gas in Mexico. The projections were developed on the basis of two scenarios for the period of 1993-2000. This period is divided into che near term (1993-1995) and the intermediate term (1996-2000). This section also addresses additions to the Mexican pipeline system and new gas export points from the United States.

\subsection{SCENARIOS FOR THE MEXICAN GAS INDUSTRY}

Projections are made on the basis of two scenarios, referred to as Scenario A and Scenario B. They differ in the degree to which environmental considerations are assumed to stimulate the usage of natural gas, in the dates when new gas-fired electrical generating stations will come on-line, and in the degree to which PEMEX will supply gas to meet the demand in the electrical sector. Scenario A is based on conservative assumptions; Scenario B is based on more optimistic assumptions that would result in greater use of natural gas. For example, the recent rate of growth of the Mexican economy has been $3 \%$ annually and is expected to continue at that rate for the immediate future (Garcia 1993). Scenario A assumes a $3 \%$ annual increase in the industrial use of natural gas to keep pace with the economy. Scenario B assumes a $4.5 \%$ annual increase in the industrial use of natural gas. This greater rate of growth of industrial gas usage has been observed during the past two years. In Scenario $B$, use is assumed to continue to grow at this rate for the immediate future as Mexican industry responds to concerns about urban air quality.

\subsection{PROJECTION OF PRODUCTION}

The officials of SEMIP and PEMEX interviewed by the authors in May 1993 agreed that production of natural gas in the immediate future will continue the trend set in the immediate past, a trend of steady to slightly decreased production. The reasons given for maintaining this trend include continuing tightness of available capital and a concern that major capital expenditures by PEMEX could have an inflationary effect on the economy. Expenditures for new exploration and production are expected to be for efforts in the South and Marine regions, because profitable crude oil will be produced there, as well as natural gas. Thus, for both scenarios, production in the North Region is assumed to continue to decline, and production in the South and Marine regions is assumed to increase to the extent that total production is maintained at approximately the 1992 level.

\subsection{PROJECTION OF CONSUMPTION BY SECTOR}

Projections for demand are made for five sectors by using sector-dependent assumptions. These sectors are (1) PEMEX petrochemicals, (2) industrial (non-PEMEX) use, 
(3) electrical generation, (4) residential and commercial use, and (5) transportation. Projections of natural gas usage for these five sectors under the two scenarios are summarized in Table 3.1, and the assumptions underlying these projections are summarized in Table 3.2. Although values are given to four figures in Table 3.1, these estimates have the uncertainties customary in projections, and only one or two figures are significant. These projections and assumptions are discussed in more detail in the following sections.

\subsubsection{PEMEX Petrochemicals}

Consumption by PEMEX petrochemical plants can be expected to decrease to about $1,070 \mathrm{MMCF} / \mathrm{d}$ in the near term as unprofitable plants (e.g., ammonia plants) are closed. The closure of unprofitable plants should be complete by 1995 . Concurrently, however, consumption in the remaining plants should grow in parallel with the Mexican economy throughout the immediate term (i.e., at the $3 \%$ annual rate discussed in Section 3.1 [Flores 1993]). As a result, the PEMEX petrochemical sector is projected to have flat consumption for the near term and a $3 \%$ annual increase in consumption for the intermediate term. These assumptions apply for both scenarios.

PEMEX has announced its intention to sell its unrestricted chemical plants to private investors. Because many of the plants are located on the same sites as refineries or basic petrochemical plants, PEMEX and prospective buyers are having difficulty coming to agreement over terms of the sale. Whatever the outcome, PEMEX will no doubt supply those plants with natural gas just as it now does (El Financiero 1993). Although future statistics may attribute gas consumption in these plants to another sector, their consumption is projected as if the plants will still be owned by PEMEX.

\subsubsection{Industrial Sector (Excluding PEMEX)}

As discussed in Section 3.1, gas usage in the industrial sector (excluding PEMEX) is assumed to increase by $3 \%$ annually in Scenario $\mathrm{A}$ and by $4.5 \%$ annually in Scenario B. Under Stenario A, usage in this sector grows to $928 \mathrm{MMCF} / \mathrm{d}$ in 1995 and to $1,075 \mathrm{MMCF} / \mathrm{d}$ in 2000. Under Scenario B, usage grows to $969 \mathrm{MMCF} / \mathrm{d}$ in 1995 and to 1,207 MMCF/d in 2000. As discussed previously, most maquiladora plants do not use process heat; consequently, their direct impact on natural gas usage is small, and their indirect impact will consist of using electricity generated by natural gas.

\subsubsection{Electrical Sector}

\subsubsection{Federal Electricity Commission (Ci E)}

No new conversions of existing generating stations are planned for the near term; however, construction of a new 700-MWe combined-cycle station, Samalayuca II (to be located 
TABLE 3.1 Projection of Consumption of Natural Gas by Sector

\begin{tabular}{|c|c|c|c|c|c|c|c|}
\hline \multirow[b]{3}{*}{ Sector } & \multicolumn{7}{|c|}{ Gas Consumption (MMCF/d) } \\
\hline & \multirow[b]{2}{*}{1992} & \multicolumn{3}{|c|}{ Scenario A } & \multicolumn{3}{|c|}{ Scenario B } \\
\hline & & 1993 & 1995 & 2000 & 1993 & 1995 & 2000 \\
\hline \multicolumn{8}{|l|}{ PEMEX } \\
\hline Petrochemical & 1,121 & 1,070 & 1,070 & 1,240 & 1,070 & 1,070 & 1,240 \\
\hline \multicolumn{8}{|l|}{ Non-PEMEX } \\
\hline Industrial & 849 & 874 & 928 & 1,075 & 887 & 969 & 1,207 \\
\hline Electrical & 427 & 410 & 410 & 790 & 427 & 440 & 1,010 \\
\hline $\begin{array}{l}\text { Residential/ } \\
\text { commercial }\end{array}$ & 90 & 90 & 95 & 110 & 90 & 110 & 200 \\
\hline Transportation & $-a$ & $-{ }^{a}$ & $-{ }^{a}$ & $--^{a}$ & $--^{a}$ & 10 & 400 \\
\hline Total non-PEMEX & 1,366 & 1,374 & 1,433 & 1,995 & 1,404 & 1,529 & 2,817 \\
\hline
\end{tabular}

a Consumption in the transportation sector is assumed to be negligible.

about $30 \mathrm{mi}$ south of Ciudad Juárez), is now under contract to a consortium consisting of three U.S. companies (Bechtel, Coastal, and General Electric) and one Mexican company (ICA Industrial). The plant will consist of three combined-cycle units, each consuming natural gas at $35 \mathrm{MMCF} / \mathrm{d}$. The plant will be owned by CFE (technically, the plant will be leased by CFE, which will purchase the plant from the consortium for $\$ 1$ at the end of the term). Samalayuca II will be fueled by gas imported from the United States, and a new pipeline will be constructed by the consortium (but will be owned by PEMEX) as part of the project. The first unit is scheduled for completion in late 1995. Thus, in the near term, the only increase in the use of gas for the electrical sector would result from providing a supply sufficient for gas-fired units in the North to operate at their full rating.

\subsubsection{Independent Power Production}

In the intermediate term (1996-2000), two major gas-fired generating projects are planned. These projects will not be owned by CFE; rather, they would be privately owned IPP facilities that will sell electricity to CFE pursuant to the recent changes in the Public Service Law for Electrical Energy. These IPPs will be located at Merida in Yucatan and at Rosarito in Baja California. 
TABLE 3.2 Summary of Assumptions for Scenarios A and B

\begin{tabular}{|c|c|c|c|c|}
\hline \multirow[b]{2}{*}{ Sector } & \multicolumn{2}{|c|}{ Scenario A (Conservative) } & \multicolumn{2}{|c|}{ Scenario B (Optimistic) } \\
\hline & Near Term & Intermediate Term & Near Term & Intermediate Term \\
\hline PEMEX & $\begin{array}{l}\text { Compensating decreases from } \\
\text { closing of unprofitable plants } \\
\text { and increases in line with } \\
\text { general Mexican economy keep } \\
\text { usage constant after initial } \\
\text { decline in } 1993 \text {. }\end{array}$ & $\begin{array}{l}\text { Usage increases by } 3 \% \\
\text { annually, keeping pace with } \\
\text { general Mexican economy. }\end{array}$ & Same as near term for Scenario $A$. & $\begin{array}{l}\text { Same as intermediate term for } \\
\text { Scenario A. }\end{array}$ \\
\hline $\begin{array}{l}\text { Industrial } \\
\text { (non-PEMEX) }\end{array}$ & $\begin{array}{l}\text { Usage increases by } 3 \% \\
\text { annually, keeping pace with } \\
\text { general Mexican economy. }\end{array}$ & $\begin{array}{l}\text { Usage increases by } 3 \% \\
\text { annually, keeping pace with } \\
\text { general Mexican economy. }\end{array}$ & $\begin{array}{l}\text { Usage increases by } 4.5 \% \text { annually, } \\
\text { continuing the trend of the last } \\
\text { two years. }\end{array}$ & $\begin{array}{l}\text { Usage increases by } 4.5 \% \\
\text { annually, continuing the trend } \\
\text { of the last two years. }\end{array}$ \\
\hline Electrical & $\begin{array}{l}\text { No new conversions; existing } \\
\text { stations do not get sufficient } \\
\text { supply for optimum operation. }\end{array}$ & $\begin{array}{l}\text { Samalayuca II operates at full } \\
\text { capacity in } 2000 \text {; Mérida and } \\
\text { Rosarito operate at half } \\
\text { capacity in } 2000 .\end{array}$ & $\begin{array}{l}\text { No new conversions; existing } \\
\text { stations get sufficient supply for } \\
\text { optimum operation. }\end{array}$ & $\begin{array}{l}\text { Samalayuca II, Mérida, and } \\
\text { Rosarito all operate at full } \\
\text { capacity in } 2000 .\end{array}$ \\
\hline $\begin{array}{l}\text { Residential } \\
\text { commercial }\end{array}$ & Slow and steady increases. & Slow and steady increases. & Government encouragement. & $\begin{array}{l}\text { Usage doubles to } 200 \mathrm{MMCF} / \mathrm{d} \\
\text { by } 2000 .\end{array}$ \\
\hline Transportation & No significant gas usage. & No significant gas usage. & $\begin{array}{l}\text { Impediments beginning to be } \\
\text { removed. }\end{array}$ & $\begin{array}{l}100,000 \text { vehicles converted by } \\
2000 \text {. }\end{array}$ \\
\hline
\end{tabular}


Preliminary requirements for the Mérida plant have been prepared. The plant is expected to consist of two 200-MWe combined-cycle units fueled with associated gas produced in the South. Construction of a new gas pipeline would be required. The plant would come on-line after 1995 and would require natural gas at up to $125 \mathrm{MMCF} / \mathrm{d}$ (Blanco and Cristerna 1993).

The CFE is planning for a new IPP at Rosarito. The plant would be built in stages, but no decision has been reached on the schedule and final size. In addition, the existing oil-fired plant at Rosarito would be converted to gas. Gas at up to $250 \mathrm{MMCF} / \mathrm{d}^{4}$ could be required. Two alternatives are being considered for importing gas: in one, the gas would flow directly from southern California; in the other, gas would come through a new 150-mi-long pipeline to be constructed south of the U.S. border from Yuma, Arizona (PEMEX 1991a).

\subsubsection{Cogeneration and Other Privately Owned Generation Projects}

The press has reported on gas-fired cogeneration or IPP projects, especially projects that would be located in the North. One such facility would be owned by the Alfa Group, an industrial conglomerate, and would be located in Altamira on the Gulf of Mexico. Electrical output from the facility would be wheeled by CFE to Alfa plants in Monterrey. Another such facility would be located in Reynosa, near the U.S. border, and again the electricity would be wheeled to industrial plants in Monterrey (Garcia 1993). No separate projection of natural gas consumption for such projects is made, because that consumption is included in the projection of overall industrial use.

\subsubsection{Projections}

Under the conservative Scenario A, PEMEX would continue to limit the supply of domestic gas to electrical generating plants in the North to the late 1992 level (410 MMCF/d) for the immediate term, and no new electrical generating stations would be built or converted in the near term. The Samalayuca II plant would not come on-line until 2000 (and would operate at full capacity that year), the Mérida plant would be staged so that only one unit would be in operation in 2000 , and the Rosarito project would be staged so that only half would be complete and operating in 2000 . With these assumptions, use in the electrical sector would remain at the late 1992 level until 1995 and would rise to about $790 \mathrm{MMCF} / \mathrm{d}$ at the end of the century.

Under the optimistic Scenario B, PEMEX would provide the full supply needed to run existing CFE plants at their optimal ratings. The Samalayuca II, Mérida, and Rosarito

4 This value is from PEMEX (1992a, p. 164); however, U.S, sources (DOE 1992) indicate a value of $260 \mathrm{MMCF} / \mathrm{d}$. The difference may be the result of different methods of measurement. Where calculations are based on references in Mexican data, the value of $250 \mathrm{MMCF} / \mathrm{d}$ is used. 
generating stations are all assumed to be completed for a full year of operation at full capacity in 2000. In Scenario B, use of gas would grow from the present $427 \mathrm{MMCF} / \mathrm{d}$ to $440 \mathrm{MMCF} / \mathrm{d}$ by 1995 and to $1,010 \mathrm{MMCF} / \mathrm{d}$ by 2000 .

\subsubsection{Residential/Commercial Sector}

In the near term, expansion of the local gas distribution companies currently operating is estimated to be limited because of the lengthy procedure needed to obtain permits from local authorities for expansion. Approval by SECOFI for operation of the five new companies is also proceeding slowly. Therefore, little or no increase in consumption in this sector is foreseen in the near term. Growth in the intermediate term is expected to be slow but steady. The president of the Mexican Gas Association indicated that the most optimistic prospect would be a doubling of usage by 2000 (Vazquez 1993).

Under the conservative Scenario A, small increases are projected, with use rising to $95 \mathrm{MMCF} / \mathrm{d}$ in 1995 and to $110 \mathrm{MMCF} / \mathrm{d}$ in 2000 . The increase would occur because some of the new distribution companies (Table 2.4) would begin operating. Under Scenario B, in which the Mexican government takes an aggressive posture to promote the use of natural gas in this sector, little change would be expected by 1995 , but the potential exists for use to increase from the present level of $90 \mathrm{MMCF} / \mathrm{d}$ to about $200 \mathrm{MMCF} / \mathrm{d}$ in 2000.

\subsubsection{Transportation Sector}

Substantial use of natural gas in the transportation sector is unlikely by 2000 , unless the Mexican government acts to remove impediments (e.g., issues emission standards or avoids taxing natural gas so heavily that no financial incentive to converting exists). Sr. Vazquez, president of the Mexican Gas Association, has estimated that for the most optimistic scenario, about 100,000 gas-fueled vehicles would be in use by 2000 (Vazquez 1993). In Scenario A, efforts to use natural gas as a fuel in transportation would fail as a result of some combination of regulatory uncertainties, taxes that remove incentives to convert, and inadequate infrastructure. Thus, under Scenario A, gas usage in the transportation sector would continue to be negligible. In Scenario B, the assumptions are made that these impediments would be gradually removed and that the Mexico City program would be fairly successful, so that by 2000 , about 100,000 CNG-powered vehicles would be in use. On the basis of information on usage per vehicle from a report on the Mexico City program (DDF 1992), the assumption is that these 100,000 vehicles would use $400 \mathrm{MMCF} / \mathrm{d}$.

\subsubsection{Summary of Projections of Consumption by Sector}

Table 3.1 and Table 3.2, presented earlier, summarize the projections and assumptions of the two scenarios used. Overall, under the conservative Scenario A, usage (excluding usage by PEMEX) would rise from the present 1,366 MMCF/d to 1,433 MMCF/d in 1995 and to $1,995 \mathrm{MMCF} / \mathrm{d}$ in 2000. Under the optimistic Scenario B, usage (again 
excluding use by PEMEX) would rise from the present level to 1,529 MMCF/d in 1995 and to $2,817 \mathrm{MMCF} / \mathrm{d}$ in 2000 .

\subsection{ADDITIONS TO THE MEXICAN PIPELINE INFRASTRUCTURE}

Each of the three new gas-fired electrical generating stations discussed in Section 3.3.3 requires the construction of a new pipeline. All three pipelines would be owned by PEMEX, although private investors are to be involved in their construction. One part of the Samalayuca II project is the construction of a new pipeline between the Samalayuca power plant and the international border west of Ciudad Juárez. The pipeline would be approximately $26 \mathrm{mi}$ long and would connect on the north with a new border crossing point (described in Section 3.5) and on the south with the existing 16-in.-diameter Chihuahua-Ciudad Juárez pipeline. The new pipeline would have a capacity of $300 \mathrm{MMCF} / \mathrm{d}$ and would permit increased delivery of natural gas to those cities for industrial and residential/commercial use.

A new 330-mi-long pipeline would be needed to service the Mérida project. The pipeline would replace the existing smaller pipeline between Ciudad Pemex and Mérida. A 30-in.-diameter line has been proposed, with a capacity of $300 \mathrm{MMCF} / \mathrm{d}$, to provide for potential extension to other points in the Yucatan (PEMEX 1991a).

A new pipeline would be needed to service the electrical generating plant at Rosarito in Baja California, because no gas service exists in that state. One option under consideration is a 154-mi-long pipeline from a border crossing at Yuma, Arizona. The other is a 20-mi-long pipeline from a proposed border crossing at San Isidro, California. Both pipelines would have a diameter of $36 \mathrm{in}$. Which pipeline will be constructed depends on which consortium is chosen to build the Rosarito station.

\subsection{NEW U.S. GAS EXPORT POINTS}

Five proposed crossings are now under consideration at FERC: (1) a 600-MMCF/d pipeline at Hidalgo, Texas; (2) a 300-MMCF/d pipeline at El Paso, Texas; (3) a small pipeline at Sunland Park, New Mexico, with a capacity of 25-50 MMCF/d; (4) a 350-MMCF/d pipeline at Yuma, New Mexico; and (5) a pipeline with a potential capacity of $500 \mathrm{MMCF} / \mathrm{d}$ at San Isidro, California. Houston Pipeline Company has been granted a presidential permit for the siting of facilities at the international border in Hidalgo County, Texas (FERC Docket No. CP92-417). The river crossing would consist of approximately $1,400 \mathrm{ft}$ of 36 -in. pipeline, to be constructed by direct drilling under the Rio Grande. In addition to the crossing itself, approximately $100 \mathrm{ft}$ of 36-in. pipeline would be required to connect with the PEMEX 42-in. line at Reynosa, and $22.6 \mathrm{mi}$ of 36 -in. pipeline would be required to connect with Houston Pipeline Company's existing system in southern Texas. This border crossing would have a capacity of $600 \mathrm{MMCF} / \mathrm{d}$. 
The El Paso Natural Gas Company has filed a permit application with FERC for a new 300-MMCF/d crossing for the Samalayuca expansion project (FERC Docket No. CP93-252-000) and for a presidential permit for the border crossing, approximately $6 \mathrm{mi}$ south of Clint, Texas (FERC Docket No. CP93-252-000). The project involves approximately $0.2 \mathrm{mi}$ of 24-in. pipeline at the Rio Grande crossing, $21 \mathrm{mi}$ of 24-in. pipeline from the Hueco Compressor Station of El Paso Natural Gas to the river crossing and $15 \mathrm{mi}$ of 30-in. pipeline between the Cornudas (Texas) and Hueco compressor stations. Three new compressor units totaling 32,800 horsepower would also be required. The new border crossing would connect with the proposed new pipeline in the Samalayuca II project discussed in Sections 3.3.3.1 and 3.4.

The Gas Company of New Mexico has tiled a permit application for construction of an 8-in. pipeline and for a presidential permit for a border crossing at Santa Teresa, New Mexico (FERC Docket No. CP93-93 and CP93-98). The new pipeline would connect the two sides at the Santa Teresa International Industrial Park, which spans the border. The pipeline would initially deliver 25-30 MMCF/d into the park, which is now supplied by an inadequate existing branch from the PEMEX Chihuahua-Ciudad Juárez pipeline system.

The El Paso Natural Gas Company has also filed for a new border crossing at Yuma, Arizona (FERC Docket No. CP93-117 and CP93-119). The border crossing would be a 36-in. pipeline with a capacity of $350 \mathrm{MMCF} / \mathrm{d}$. The border crossing would connect with a proposed 154-mi-long pipeline to be constructed to supply gas for the new IPP plant at Rosarito in Baja California. The El Paso Natural Gas Company project would entail construction of a 90-mi-long, 30-in.-diameter line east of Yuma to parallel the company's presently operating 10-in. pipeline.

The San Diego Gas and Electric Company has filed for construction of a border crossing at San Isidro, California (FERC Docket No. CP92-580 and CP92-581). Two options are proposed. The first option, which would create a capacity of $145 \mathrm{MMCF} / \mathrm{d}$, entails construction of short spurs to San Diego's existing line on the Otay Mesa to the border crossing. The second option involves construction of a 100-mi-long transmission pipeline with a capacity up to $500 \mathrm{MMCF} / \mathrm{d}$ to connect the Southern California Gas Company's main line to the border crossing. 


\section{ESTIMATE OF THE MARKET FOR U.S. EXPORTS}

In this section, the projections of production and consumption of natural gas in Mexico are used to estimate the market for exporting natural gas from the United States to Mexico in the immediate future. The section also discusses how balance-of-payments considerations and the availability of Canadian natural gas may affect the market.

\subsection{PROJECTION OF U.S. EXPORTS OF NATURAL GAS TO MEXICO}

For several years, PEMEX has purchased natural gas from the United States to make up the difference between what PEMEX supplies to non-PEMEX users and what remains from domestic production after the needs of PEMEX facilities are met. This report projects exports from the United States to Mexico with the assumption that this pattern will continue in the immediate future; that is, we assume that domestic natural gas production will be steady, that all foreign natural gas purchases will be from the United States, and that PEMEX will not curtail sales to reduce imports because of issues involving Mexico's balance of payments. The projected exports of natural gas to Mexico under the two scenarios described in Section 3 are tabulated in Table 4.1 and depicted in Figure 4.1.

As shown in Table 4.1, U.S. exports are expected to decrease in 1993 by nearly $20 \%$. This decrease can be attributed to the fact that gas was made available for domestic use by the closing of the unprofitable PEMEX plants; however, U.S. exports would return to the 1992 level in 1995 under Scenario A and would increase above the 1992 level to $362 \mathrm{MMCF} / \mathrm{d}$ in 1995 under Scenario B. Beyond 1995, U.S. exports should increase to help supply the requirements of the Samalayuca II and Rosarito projects. In addition, the demand for exports from the United States should increase, because PEMEX will be providing less domestic gas to non-PEMEX users as use in its own facilities parallels the growth in the Mexican economy. Finally, U.S. exports would also increase to help supply the additional gas needed to support overall growth of the Mexican economy. Under Scenario B, the transportation sector would begin to consume significant quantities of natural gas. Under Scenario A, these exports would rise to $978 \mathrm{MMCF} / \mathrm{d}$ in 2000; under Scenario B, they would reach $1920 \mathrm{MMCF} / \mathrm{d}$.

\subsection{ADEQUACY OF THE EXPORT PIPELINES}

Under Scenario A, U.S. exports to Mexico would increase from the 1992 level of $250 \mathrm{MMCF} / \mathrm{d}$ to approximately $980 \mathrm{MMCF} / \mathrm{d}$ by 2000 . The electrical sector accounts for the largest share of the increase, which would result in increases at the El Paso border crossing and the new export point to serve Rosarito. The exports at El Paso are projected to be about $190 \mathrm{MMCF} / \mathrm{d}$, which is well within the capacity of the 300-MMCF/d pipeline now being constructed. Either of the proposed border crossings would have the capacity for that project. The projected increase in consumption by non-PEMEX industrial users would be reflected 
TABLE 4.1 Projections of U.S. Exports of Natural Gas to Mexico, 1993-2000

\begin{tabular}{|c|c|c|c|c|c|c|c|}
\hline \multirow[b]{3}{*}{ Sector } & \multicolumn{7}{|c|}{ Natural Gas (MMCF/d) } \\
\hline & \multirow[b]{2}{*}{$1992^{a}$} & \multicolumn{3}{|c|}{ Scenario A } & \multicolumn{3}{|c|}{ Scenario B } \\
\hline & & 1993 & 1995 & 2000 & 1993 & 1995 & 2000 \\
\hline Production & 2,237 & 2,237 & 2,237 & 2,237 & 2,237 & 2,237 & 2,237 \\
\hline $\begin{array}{l}\text { PEMEX petrochemical } \\
\text { consumption }\end{array}$ & 1,121 & 1,070 & 1,070 & 1,240 & 1,070 & 1,070 & 1,240 \\
\hline $\begin{array}{l}\text { Available for other } \\
\text { domestic users } b\end{array}$ & 1,116 & 1,167 & 1,167 & 997 & 1,167 & 1,167 & 997 \\
\hline $\begin{array}{l}\text { Total consumption by } \\
\text { non-PEMEX users }\end{array}$ & 1,366 & 1,374 & 1,433 & 1,975 & 1,404 & 1,529 & 2,817 \\
\hline U.S. exports ${ }^{c}$ & $250^{d}$ & 207 & 256 & 978 & 237 & 362 & 1,920 \\
\hline
\end{tabular}

a Data from PEMEX (1992a, p. 164).

b Difference between dry gas production delivered to pipelines and consumption in PEMEX petrochemical facilities.

c Difference between total consumption by non-PEMEX users and supplies available to those users from indigenous sources.

d This value is from PEMEX (1992a, p. 164); however, U.S. sources (DOE 1992) indicate a value of $260 \mathrm{MMCF} / \mathrm{d}$. The difference may be the result of different methods of measurement. Where calculations are based on references to Mexican data, a value of $250 \mathrm{MMCF} / \mathrm{d}$ has been used.

primarily in increased exports at the Hidalgo (Texas) and Penitas (Texas) export points. Thus, exports through the Hidalgo-Penitas crossings are projected to be 490-500 MMCF/d, which is easily within the 770-MMCF/d capacity of the two existing export points.

Under Scenario B, exports would rise to $1,920 \mathrm{MMCF} / \mathrm{d}$ in 2000 , with the new electrical generation projects accounting for a major share of the increased consumption. In that scenario, the proposed export pipelines at El Paso and for Rosarito would have sufficient capacity; however, exports at Penitas and Hidalgo are projected to be about $200 \mathrm{MiMCF} / \mathrm{d}$ above the total capacity of $770 \mathrm{MMCF} / \mathrm{d}$ of the existing pipelines. The proposal for a new 600-MMCF/d border crossing made by Houston Pipeline Company could satisfy the demand. 


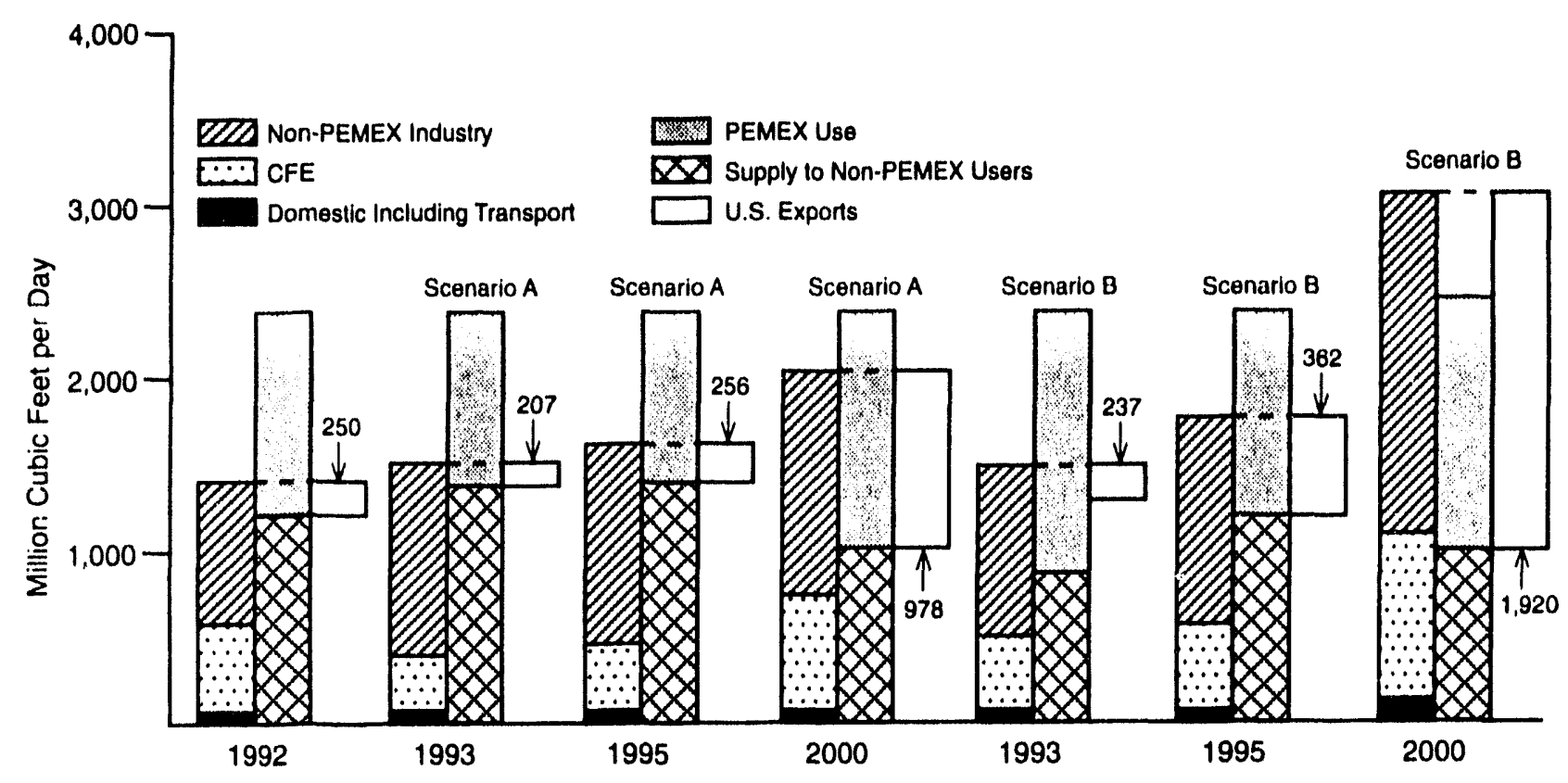

FIGURE 4.1 Use and Projected Use of Natural Gas in Mexico, 1992-2000

\subsection{BALANCE-OF-PAYMENTS CONSIDERATIONS}

Operations by PEMEX are and have been an important positive element in Mexico's balance of payments. As shown in Table 4.2, PEMEX exports of crude oil have contributed $\$ 7-9$ billion (U.S. dollars) to that balance in the years of 1990-1992. When Mexico began importing natural gas from the United States, the cost of those imports was a small element in the petroleum products balance, compared to other PEMEX imports; however, by 1992, the cost of gas imports had risen to $11.5 \%$ of PEMEX import costs and, perhaps more importantly, to $2.7 \%$ of the positive balance.

Over the period of rising U.S. exports of gas to Mexico (1988-1992), the unit cost of gas being exported decreased from the previous $\$ 3.00 / \mathrm{MCF}$ level to a mid-1992 low of $\$ 1.60 / \mathrm{MCF}$. Since then, unit prices have been rising, and the recent average unit price of exports to Mexico was $\$ 1.91 / \mathrm{MCF}$. If we assume that price ( $\$ 1.91 / \mathrm{MCF}$ ) is maintained until 2000 , the cost for natural gas imports in 2000 would be $\$ 680$ million for Scenario $A$ and $\$ 1,338$ million for Scenario B. These amounts would be significant import costs for Mexico. If the price of natural gas rose, the impact would be exacerbated.

PEMEX could change its policy and take actions not considered in the scenarios to reduce the quantity of gas imported. Two such actions might be (1) increasing investment in exploration and production of Mexican gas to increase production and (2) imposing further limits on supplies to non-PEMEX users to decrease consumption. Since natural gas imports are the difference between consumption and domestic production, increasing production, decreasing consumption, or both would result in lower U.S. exports to Mexico than those projected in the scenarios. 
TABLE 4.2 Value of Petroleum Products Exported from and Imported to Mexico

\begin{tabular}{|c|c|c|c|c|c|c|}
\hline \multirow[b]{3}{*}{ Product } & \multicolumn{6}{|c|}{ Value (million U.S. \$) } \\
\hline & \multicolumn{2}{|c|}{1990} & \multicolumn{2}{|c|}{1991} & \multicolumn{2}{|c|}{1992} \\
\hline & Exports & Imports & Exports & Imports & Exports & Imports \\
\hline Crude & $8,899.9$ & 0 & $7,267.6$ & 0 & $7,421.2$ & 0 \\
\hline Other Oil Products ${ }^{a}$ & 811.1 & 847.1 & 634.3 & $1,042.0$ & 691.4 & $1,240.5$ \\
\hline Petrochemicals & 235.9 & 91.9 & 246.2 & 105.2 & 246.1 & 137.7 \\
\hline Natural Gas & 0 & 31.0 & 0 & 106.0 & 0 & 179.5 \\
\hline Total & $9,946.9$ & 970.0 & $8,148.1$ & $1,253.4$ & $8,315.9$ & $1,557.6$ \\
\hline Net Balance & \multicolumn{2}{|c|}{$8,976.9$} & \multicolumn{2}{|c|}{$6,894.7$} & \multicolumn{2}{|c|}{$6,758.3$} \\
\hline
\end{tabular}

a Gasoline, LPG, etc.

Sources: PEMEX (1991b, 1992a).

\subsection{MEXICAN POLITICAL AND ECONOMIC CONSIDERATIONS}

The projections in this report are based primarily on an analysis of events in the energy sector in the past five years. During this period, largely under the Salinas administration, the major changes affecting the Mexican natural gas industry were the reorganization of PEMEX and the passage of new legislation allowing limited privatization in the electrical sector. Also, the numbers of basic and secondary petrochemicals were reduced to allow private industry a greater role in petrochemical production.

Privatization in the electrical sector is going forward, as shown by the planning of independent power production for Mérida and Rosarito. The Mexican Constitution gives PEMEX a monopoly on the ownership and transport of natural gas in Mexico prior to first sale. Operators of those electrical projects and other industrial projects will continue to negotiate with PEMEX for supplies of natural gas; and if imported gas is involved, PEMEX will negotiate with foreign suppliers. Although some analysts (Durbin 1992) in the United States have indicated that bypassing PEMEX in the purchase and transport of natural gas might be possible, the authors found no support for that view in Mexico in May 1993. Privatization of some of the roles of PEMEX after the Mexican presidential election in 1994 is possible, but discussion on this issue has so far been speculative.

\subsection{CANADA VERSUS THE UNITED STATES AS A SUPPLIER OF NATURAL GAS TO MEXICO}

The government of Canada sees an important role for Canadian participation in the supply of Canadian gas to Mexico (Foran 1991), a role that is actively being considered by PEMEX. For example, one of the consortiums vying for the Rosarito project would use 
Canadian natural gas transported to Mexico through California; PEMEX is planning for this possibility (PEMEX 1991a).

One direct export by Canada through the United States to Mexico has been reported (FERC 1992). Western Gas Marketing, Ltd. shipped 306 MMCF from Alberta to Mexico via the Northern Border Pipeline Co., Natural Gas Pipeline Co., and Valero Gas Partners, L.P. The cost of that shipment was reported as $\$ 2.52 / \mathrm{MMBtu}$, a cost quite comparable to other shipments at the Penitas (Texas) border crossing (DOE 1992).

In this report, the assumption was made in estimating the market for export of U.S. gas to Mexico, that in the immediate future, the gas being imported by Mexico is U.S. gas; however, the projected exports could originate either in the United States or Canada. 


\section{CONCLUSIONS}

Under the conservative scenario used, exports of natural gas from the United States would drop from the 1992 level of $250 \mathrm{MMCF} / \mathrm{d}$ but would return to that level by 1995 . Exports would then increase to about $980 \mathrm{MMCF} / \mathrm{d}$ by 2000 . That scenario assumes that (1) domestic natural gas production will remain at its 1992 level, (2) PEMEX will close unprofitable plants during this period, (3) growth in consumption of gas by non-PEMEX industrial users will parallel a $3 \%$ annual growth in the general economy, (4) no new gas-fired electrical generating plants will come on-line in the near term, (5) new generating plants being planned will be in partial operation in 2000, and (6) no growth in consumption will occur in the residential/commercial and transportation sectors. The projection that exports would increase is based on the assumption that industrial consumption would continue to grow by $3 \%$ annually and that some of the gas-fired electrical generating units being planned would begin operating.

Under a more optimistic scenario, exports to Mexico would fall in 1993 but would recover and rise to about $360 \mathrm{MMCF} / \mathrm{d}$ in 1995 and to $1,920 \mathrm{MMCF} / \mathrm{d}$ in 2000. This scenario differs from the conservative scenario in that it projects that consumption of gas by non-PEMEX industrial users will increase by $4.5 \%$ annually (a growth rate greater than that of the general economy), that all of the new gas-fired units being planned will be in operation by 2000 , that consumption in the residential/commercial sector will double, and that 100,000 vehicles will be operating on natural gas.

The present gas pipelines, both at the border crossings and within the Mexican pipeline system, have the capacity to transport the projected increased gas consumption for the near term. With the addition of a pipeline for the Samalayuca project and one of the pipelines proposed for the Rosarito project, the pipeline system can transport the quantities needed for 2000; however, the projected increases in exports may not be reached if PEMEX invests in increased indigenous gas production or limits the amounts of gas that PEMEX makes available to non-PEMEX users, which it might choose to do if the cost of the projected imports increases. 


\section{REFERENCES}

ANL, 1992, database on exports and imports of natural gas to and from the United States (under development), Argonne National Laboratory, Argonne, Ill. (accessed Dec. 1992).

Barcenas, A., 1993, personal communication from Barcenas (PEMEX Gas and Basic Petrochemicals, Mexico City, Mexico) to M.A. Kanter (Argonne National Laboratory, Argonne, Ill.), May 20.

Bazan, G., 1993, personal communication from Bazan (PEMEX Gas and Basic Petrochemicals, Mexico City, Mexico), to M.A. Kanter (Argonne National Laboratory, Argonne, Ill.), May 20.

Blanco, A., and R. Cristerna, 1993, personal communication from Blanco and Cristerna (Federal Electricity Commission, Mexico City, Mexico) to M.A. Kanter and P.H. Kier (Argonne National Laboratory, Argonne, Ill.), May 19.

Bush Administration, 1991, "Free Trade Negotiations with Mexico: Environmental Matters; Response of the Bush Administration to Issues Raised in Connection with the Negotiation of a North American Free Trade Agreement, transmitted to Congress by the President on May 1, 1991," International Environmental Affairs 3:219-228.

CFE, 1986-1992, Informe de Operacion (Annual Reports), 1985-1991, Federal Electricity Commission, Mexico City, Mexico.

DDF, 1992, Programa para el Uso de Gas Licuado de Petroleo y Gas Natural Comprimido en el Autotransporte Publico y Concessionado (Program for the Use of Liquefied Petroleum Gas and Compressed Natural Gas in Public and Licensed Vehicles), Federal District Department, Mexico City, Mexico, Feb. 4 (in Spanish).

DOC, 1992, unclassified cable 38428, from U.S. Embassy, Mexico City, Mexico, to U.S. Department of Commerce, Washington, D.C., Dec. 17.

DOE, 1991-1993, Natural Gas Imports and Exports, quarterly reports, U.S. Department of Energy, Washington, D.C.

DOE, 1992, Natural Gas Monthly, U.S. Department of Energy, Washington, D.C., Aug. 
DOE/SEMIP, 1991, United States/Mexico Electricity Trade Study, DOE/IE-0020P, U.S. Department of Energy, Washington, D.C.; and Secretariat of Energy, Mines, and Public Industry, Mexico City, Mexico, March.

Durbin, W., 1992, Mexico's Economic Renaissance: Opportunities for Natural Gas and Electric Power, Cambridge Energy Research Associates, Cambridge, Mass., Jan.

El Financiero, 1993, "Petrochemical Privatization Faces Rough Ride," El Financiero International (in English), 2(47):36, May 3.

Embassy of Mexico, 1991, "Temporary Closure of 156 Polluting Industrial Plants in Mexico," press release, reproduced in North American Free Trade Agreement: Hearings, House Committee on Energy and Commerce, Subcommittee on Commerce, Consumer Protection, and Competitiveness, 102nd Congress, 1st session, March 20, May 8, and May 15, 1991 (U.S. Government Printing Office serial no. 102-15), p. 97.

FERC, 1992, "Western Gas Marketing Selling Gas to Mexico under 30-Day Contract," Gas Market Report, Inside FERC, p. 3, U.S. Federal Energy Regulatory Commission, Washington, D.C., Oct. 9.

Flores, E., 1993, personal communication from Flores (Technical Secretary, Mexican Petrochemical Commission, Mexico City, Mexico) to M.A. Kanter (Argonne National Laboratory, Argonne, Ill.), June 21.

Foran, J., 1991, Mexican Natural Gas: Potential Impacts on the North American Market, Department of Energy, Mines, and Resources, Ottawa, Ontario, Canada, Oct.

Foy, G., 1992, "Environmental Protection versus Intellectual Property: The U.S.-Mexico Free Trade Agreement Negotiations," International Environmental Affairs 4:323-337, fall.

Garcia, F., 1993, personal communication from Garcia (Center for Strategic Studies, Monterrey Institute of Technology and Higher Education, Monterrey, Nuevo León, Mexico) to M.A. Kanter and P.H. Kier (Argonne National Laboratory, Argonne, Ill.), May 20. 
GAO, 1991, letter from A.I. Mendelowitz (U.S. General Accounting Office), to Rep. John Dingell (Chairman, Committee on Energy and Commerce), reproduced in North American Free Trade Agreement: Hearings, House Committee on Energy and Commerce, Subcommittee on Commerce, Consumer Protection, and Competitiveness, 102nd Congress, 1st session, March 20, May 8, and May 15, 1991 (U.S. Government Printing Office serial No. 102-15), p. 237.

GAO, 1992, North American Free Trade Agreement: U.S.-Mexican Trade and Investment Data, GAO/GGD-92-131, U.S. General Accounting Office, Washington, D.C., Sept.

Lajous, A., 1992, "The Mexican Gas Industry - Recent Developments and Prospects," presented at the Annual Meeting of the Interstate Natural Gas Association of America, Vancouver, B.C., Canada, Sept.

NAFTA, 1992, North American Free Trade Agreement between the Government of the United States of America, the Government of Canada, and the Government of the United Mexican States, Executive Office of the President, Washington, D.C.

NPC, 1992, Potential for Natural Gas in the U.S.: Source and Supply, vol. 2, National Petroleum Council, Washington, D.C., Dec.

Official Diary (Diario Ofical de la Federacion), 1992, Reform and Amendment of the Public Service Law for Electrical Energy, Dec. 23.

Official Diary (Diario Ofical de la Federacion), 1993, Regulations of the Public Service Law for Electrical Energy, May 31.

PEMEX, 1990, Memoire de Labores - 1990 (Report on Operations), Petroleos Mexicanos, Mexico City, Mexico.

PEMEX, 1991a, Requirementos Addicionales de Gas Natural de la Commission Federal de Electricidad (Additional Requirements for Natural Gas by the Federal Electricity Commission), Petroleos Mexicanos - Subdirection de Petroquimica y Gas, Mexico City, Mexico, Nov.

PEMEX, 1991b, Memoire de Labores - 1991 (Report on Operations), Petroleos Mexicanos, Mexico City, Mexico. 
PEMEX, 1992a, Memoire de Labores - 1992 (Report on Operations), Petroleos Mexicanos, Mexico City, Mexico.

PEMEX, 1992b, Statistical Summary - 1992, Petroleos Mexicanos, Mexico City, Mexico.

Perry, D.M., et al., 1990, "Binational Management of Hazardous Waste: The Maquiladora Industry at the US-Mexico Border," Environmental Management 14(4):450-451.

SEMIP, 1992, Petroquimica 91, Mexican Petrochemical Commission, Secretariat of Energy, Mines, and Public Industry, Mexico City, Mexico, Sept.

U.S. International Trade Commission, 1993, Potential Impacts on the U.S. Economy and Selected Industries of the North American Free-Trade Agreement, USITC publication 2596, Washington, D.C.

Vazquez, L., 1993, personal communication from Vaquez (President, Mexican Gas Association, Mexico City, Mexico) to M.A. Kanter and P.H. Kier (Argonne National Laboratory, Argonne, Ill.), May 18.

White, B., 1992, "The U.S.-Mexican Natural Gas Relationship," Gas Energy Review 20(12):18-27, Dec. 


\section{APPENDIX A:}

ORGANIZATIONAL FRAMEWORK

FOR MEXICAN NATURAL GAS TECHNOLOGY 


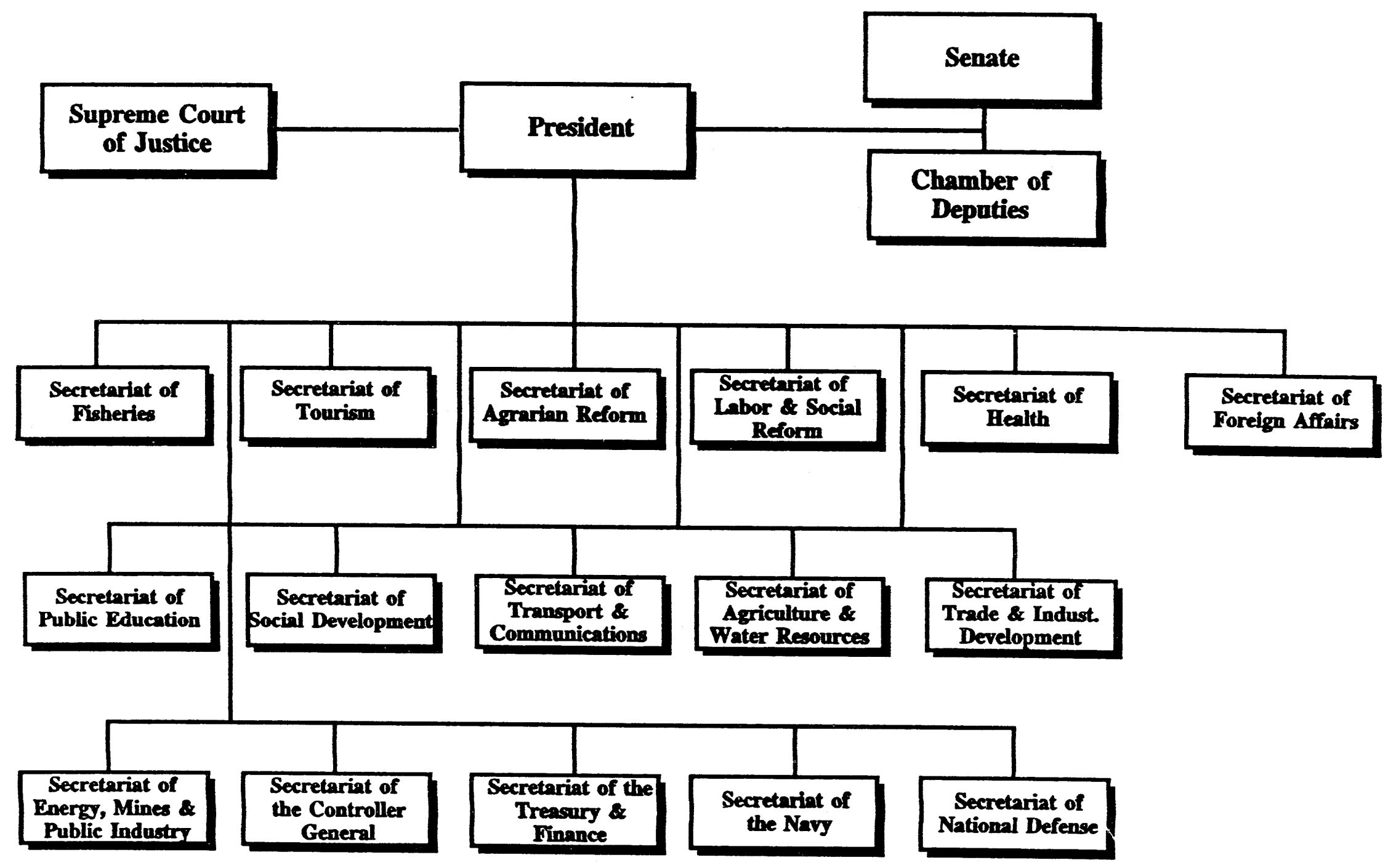

FIGURE A.1 Organization of Mexican Federal Government 


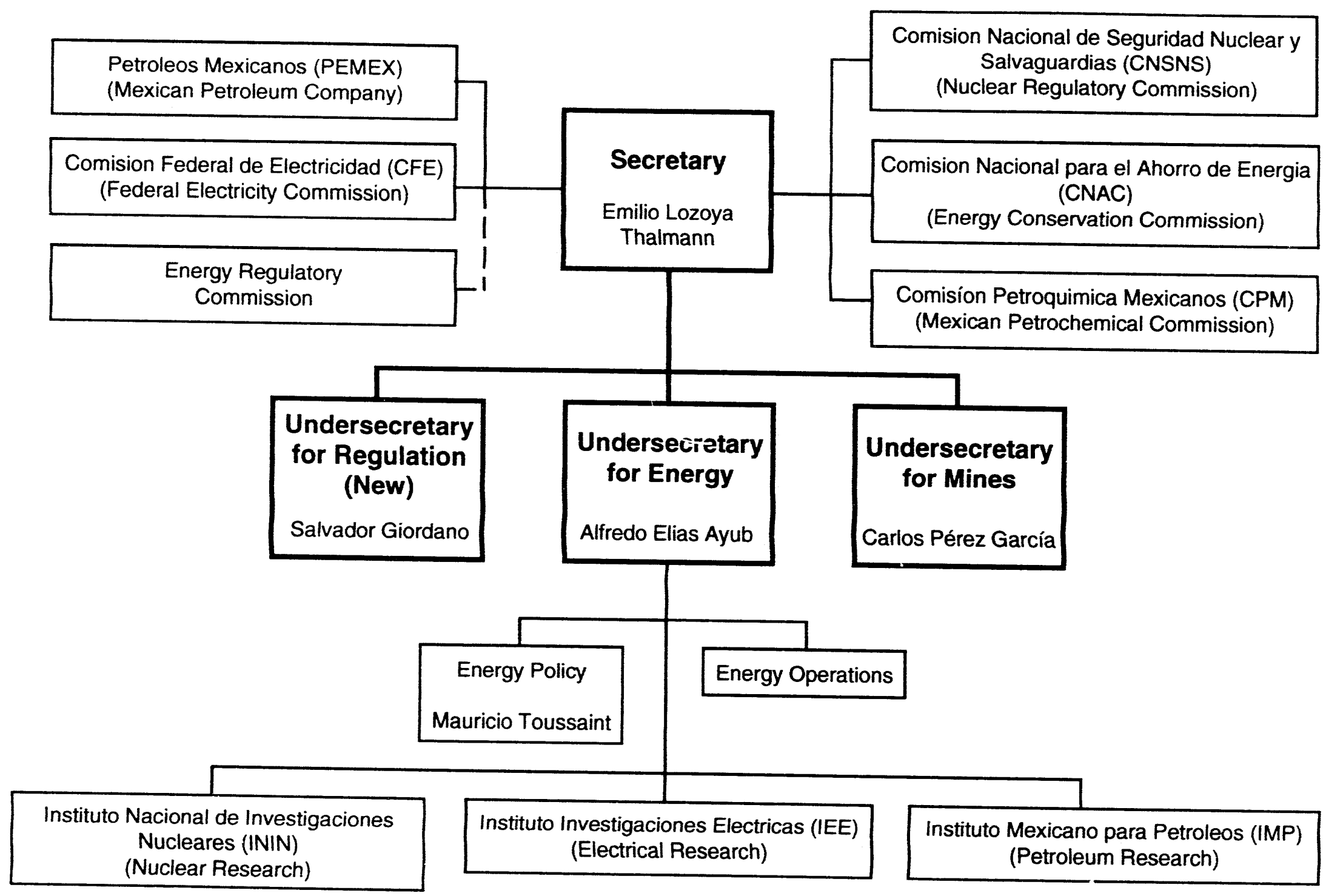

FIGURE A.2 Organization of SEMIP 


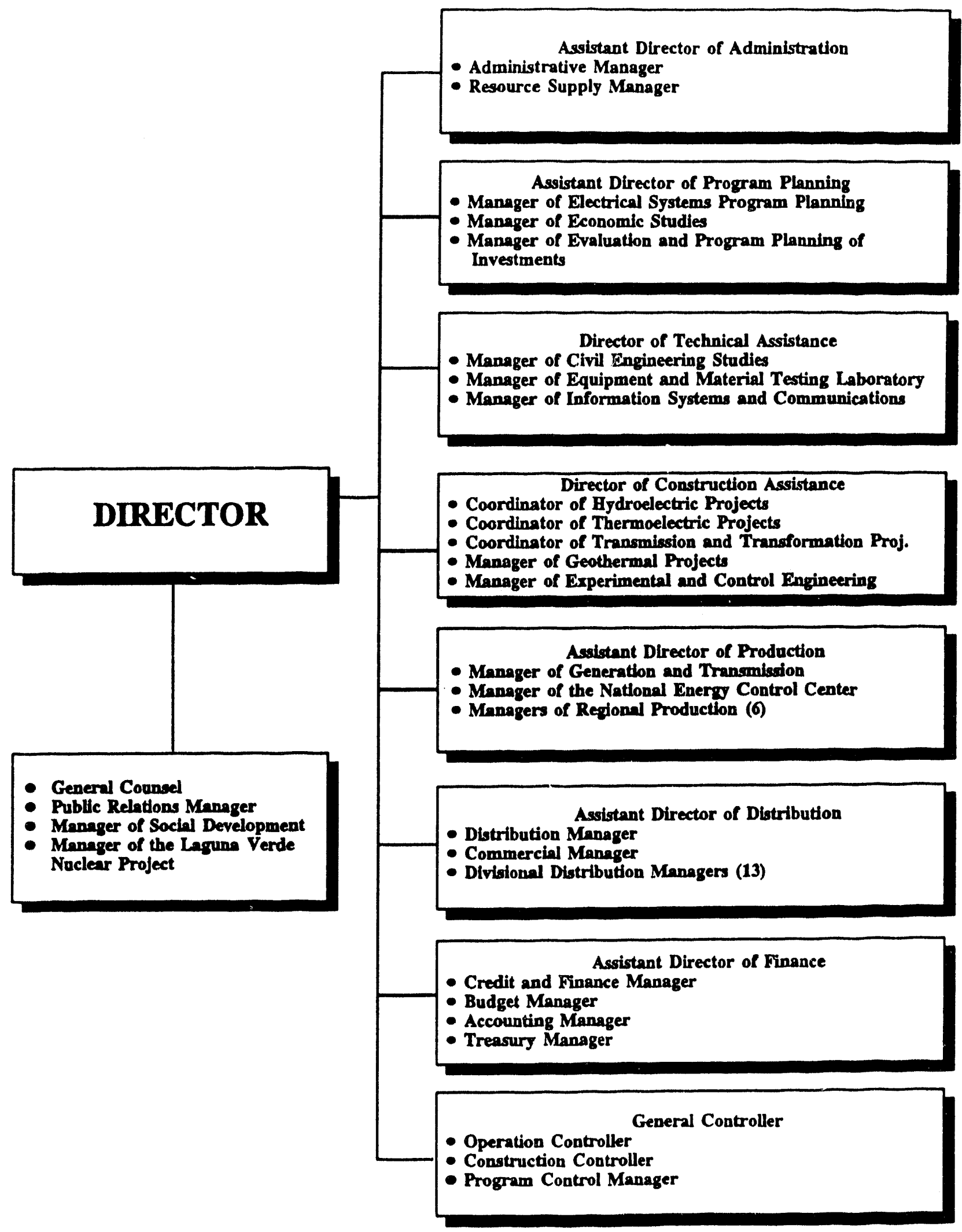

FIGURE A.3 Organization of the CFE (Source: DOE/SEMIP 1991, Figure 3.1) 

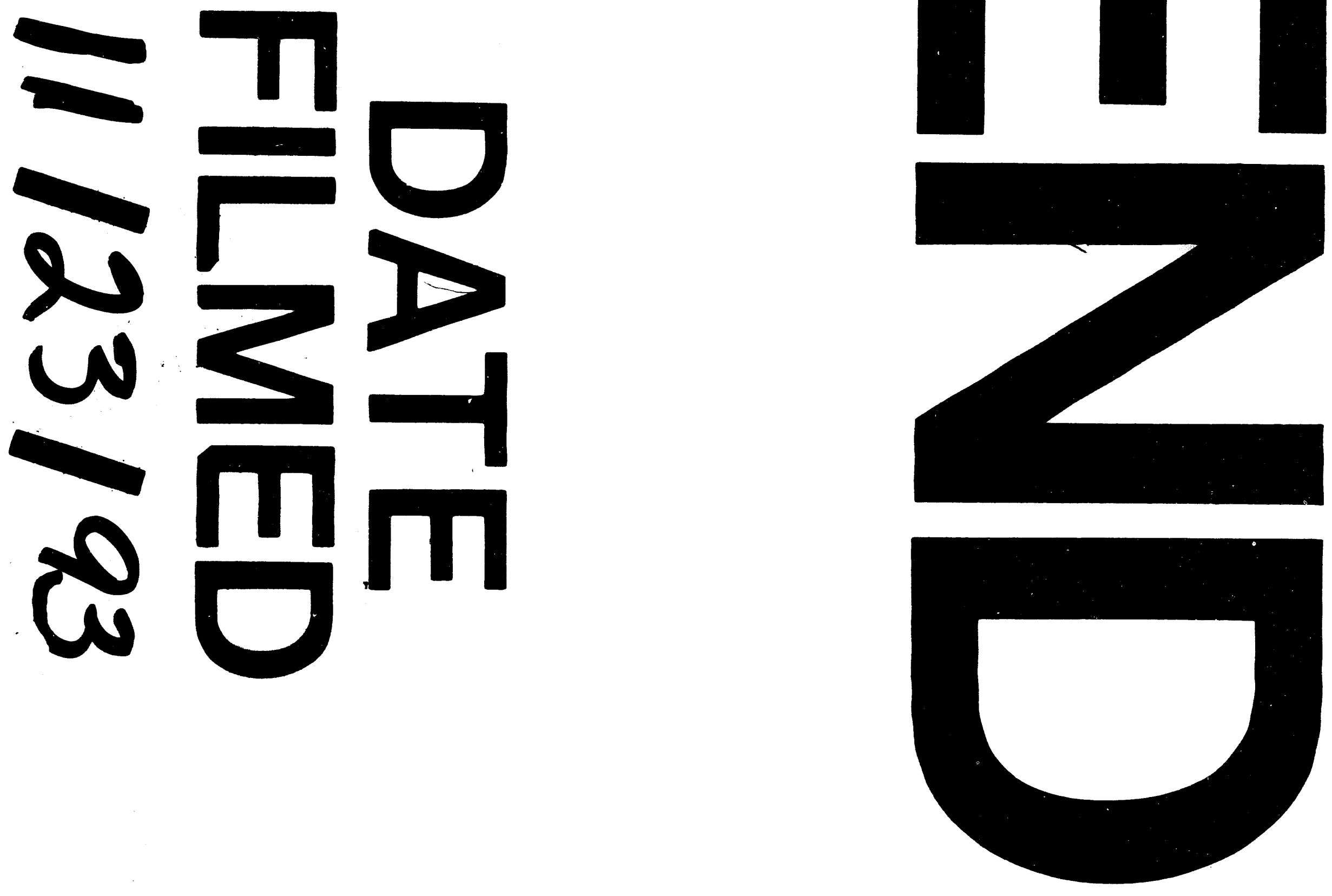
